\title{
Linking Global Value Chains and Supply Chain Management: Evidence from the Electric Motors Industry
}

\author{
Ruggero Golini*1 \\ Università degli Studi di Bergamo, Department of Management, Information and Production \\ Engineering, Via Pasubio 7, 24044 Dalmine (BG) Italy
}

Federico Caniato $^{2}$

Politecnico di Milano, Department of Management, Economics and Industrial Engineering, Piazza Leonardo da Vinci, 32, 20133 Milano, Italy

Matteo Kalchschmidt ${ }^{3}$

Università degli Studi di Bergamo, Department of Management, Information and Production Engineering, Via Pasubio 7, 24044 Dalmine (BG) Italy

To cite this article: Ruggero Golini, Federico Caniato \& Matteo Kalchschmidt (2016): Linking global value chains and supply chain management: evidence from the electric motors industry, Production Planning \& Control, DOI: 10.1080/09537287.2016.1170225

To link to this article: $\mathrm{http} / / / \mathrm{dx} . \mathrm{doi}$. org/10.1080/09537287.2016.1170225

Acknowledgements: Preliminary parts of this research (analysis of the electric motor industry and the value chain) were performed at the Center on Globalization Governance and Competitiveness (Duke University) by Marcy Lowe, Ruggero Golini, Gary Gereffi. The results of that study are published in the online report: Lowe, M, Golini, R, Gereffi, G. 2010. US Adoption of High-Efficiency Motors and Drives: Lessons Learned. Some of the results of that study are mentioned in this paper and appropriately referenced. The remainder of this paper is entirely original. The authors would like to thank Giulio Buciuni for the precious and insightful feedback provided on the manuscript.

\footnotetext{
${ }^{1}$ email: ruggero.golini@unibg.it CORRESPONDING AUTHOR

2 email: federico.caniato@polimi.it

3 email: matteo.kalchschmidt@unibg.it
} 


\begin{abstract}
The global value chain (GVC) framework and its central concept of governance are increasingly advocated as powerful tools for interpreting managerial issues with particular reference to global supply chain (SC) management. However, a gap still exists about how the GVC concepts, which have been developed at the industry level, can be applied at the company level. The aim of this work is therefore to investigate how the concepts of GVC structure and governance are related to the way the $\mathrm{SC}$ is managed. Several research propositions drawn from the literature are investigated by means of seven case studies in the electric motors industry. The results show that the GVC can be a useful framework for understanding and deploying SC management at the company level. Moreover, the analysis of the governance modes provides an effective tool to explain the existing degree of technological and operational collaboration in the SC. Finally, we show the importance of considering such contextual factors as company size and the competitive priorities of the company to move seamlessly between the GVC, at the industry level, and SC management, at the company level.
\end{abstract}

\title{
Keywords: global value chain; global supply chain management; governance; technological collaboration; operational collaboration
}

\section{Introduction}

The complexity of global supply chains (SCs) (e.g., new and more suppliers, fragmentation, risks) has increased over time (Caniato et al., 2013; Caridi et al., 2009; Holweg et al., 2011; Manuj, 2013; Manuj and Mentzer, 2008; Perona and Miragliotta, 2004). Global SCs are in fact more difficult to manage than domestic SCs (Dornier et al., 2008; MacCarthy and Atthirawong, 2003). As a result, growing academic interest has been devoted to the concept of global supply chain management (Prasad and Babbar, 2000). The literature in this field is quite fragmented: for instance, some studies have taken into account the geographic dimension (e.g., Cagliano et al., 2008; Handfield, 1994) and others the relational dimension (e.g., Hernández-Espallardo et al., 2010; Motwani et al., 1998), typically focusing on key suppliers or customers and then dyadic buyer-supplier relationships, rather than considering the entire supply chain, which includes many tiers and branches. To overcome such 
gaps, one emerging analytical approach is the Global Value Chain (GVC) framework (Gereffi et al., 2001; Gereffi et al., 2005; Humphrey and Schmitz, 2000; UNCTAD, 2013).

The GVC framework proposes a map of what is produced where, from an industry perspective, and introduces the key concepts of governance and upgrading. Governance refers to the social and organizational structure of the GVC (Gereffi, 1994; Lee, 2010), while upgrading is about how firms maintain or improve their positions in the global economy. As governance appears to be particularly interesting for the research in SC management (Abecassis-Moedas, 2006; Gereffi and Lee, 2012), in this paper we focus on this concept, while leaving upgrading to the future developments of this work.

The GVC differs from a SC as the former provides a higher-level industry view of the input-output processes, while the latter usually refers to how the flows of goods and information are managed at the company level and with its suppliers and customers. The GVC framework and its related concept governance represent one of the most promising areas of development for SC managers and researchers (Abecassis-Moedas, 2006; Gereffi and Lee, 2012) and it could help to address the "several calls for studies to focus on the entire supply network rather than focusing on interactions between isolated pairs of firms" (Pilbeam et al., 2012).

However, to the best of our knowledge, there is a lack of systematic contributions that join the GVC and the SC management ${ }^{4}$ domains.

The GVC framework has been widely used in the fields of economic development and industry-level analysis of patterns of globalization (e.g., Gibbon, 2001; Giuliani et al., 2005; Humphrey and Schmitz, 2000), but its application in the field of SC management remains underexplored. Therefore, we deem that investigating this missing link can be crucial for both theory and practice, as the alignment between network structure, governance and management can lead to higher network effectiveness (Provan and Kenis, 2008).

\footnotetext{
${ }^{4}$ In this paper we refer to SC management from a company perspective, as the set of practices adopted in relation to collaboration with suppliers and customer in both the product development (i.e., technological collaboration) and the production-logistic (i.e., operational collaboration) processes.
} 
Therefore, the research question we want to address in this paper is: how are the GVC and governance related to the way in which the SC is geographically organized and managed?

To provide an answer to this question, we applied the GVC framework to a set of in-depth case studies in the electric motor industry and we have established a connection with the way the SC is geographically organized and managed. The paper is structured as follows. In the theoretical background, we report the state of the art of the literature about global GVC and SC management. Drawing upon the literature, we develop several preliminary research propositions that establish a connection between these two fields. Next, in the methodology chapter, we describe the set of case studies employed, and we provide details about the industry considered. Subsequently, in the results chapter, we present the analysis of the case studies, which is further developed in the discussion section. Finally, we synthesize the main findings, limitations and further developments in the conclusions.

\section{Theoretical background}

\section{Global value chains and governance}

GVC analysis has been developed in the economic and industrial trade literature (e.g., Gereffi et al., 2005) and consists of a map of the activities from raw materials to end users, highlighting the geographic locations of players and their mutual relationships. In contrast to Porter's value chain, the GVC framework includes all of the firms in the chain. This framework is gaining increasing popularity in the economic development field (UNCTAD, 2010, 2013; World Economic Forum, 2012), but also in the SC management area (Abecassis-Moedas, 2006; Chiarvesio and Di Maria, 2009; Fleury, 1999; Gereffi and Lee, 2012). In fact, given its focus on the global and dynamic nature of contemporary supply chains, the GVC approach has the potential to overcome some of present the limitations in the field of SC management (Gereffi and Lee, 2012; Stank et al., 2011; Stock et al., 2010). 
As mentioned before, one of the pillars of the GVC framework is governance. Governance of interfirm networks is not a new topic in the SC management literature. Grandori and Soda (1995) define an inter-firm network as a "mode of regulating interdependence between firms which is different from the aggregation of these units within a single firm and form coordination through market signals (prices, strategic moves, tacit collusion, etc.) and which is based on a cooperative game with partnerspecific communication". In their literature review, Pilbeam et al. (2012) identify a broad variety of instruments for governing such networks, both formal (e.g., standards, legal contracts) and informal (e.g., values, tacit norms, information sharing). Network governance has also been put in relationship with performance (Aulakh and Gencturk, 2000; Claro et al., 2003).

In the GVC framework, governance is the outcome of three determinants (Gereffi et al., 2005; Sturgeon, 2002): the complexity of the transaction, which implies the transfer of knowledge related to product and process specifications; the ability to codify transactions, which relates to possible transaction-specific investments; the capabilities in the supply base, which refer to the "actual and potential suppliers in relation to the requirements of the transaction" (Gereffi et al., 2005). The GVC framework considers a broader set of governance forms compared to the rest of the literature (Yu et al., 2006). More in detail, five typologies of buyer-supplier relationships are identified, namely, market, modular, relational, captive and hierarchy, which underpin an increasing degree of explicit coordination and power asymmetry ${ }^{5}$. In particular, when complexity is high, the ability to codify transactions is low and the capabilities in the supply base are low, the governance moves toward hierarchy (i.e., vertical integration). When the conditions are reversed, the governance moves towards market-based (arm-length). In between, the modular, relational and captive models are found with increasing degrees of explicit coordination. Ponte and Gibbon (2005) state that such of forms of governance can vary in the different segments of a GVC, thus making this concept adaptive to different buyer-supplier relationships in a multi-tier supply chain. Moreover, taking into account the geographical dimension, the study of governance in the GVC offers the possibility to examine how governance forms change when SC partners are located in the same region or in another country

\footnotetext{
${ }^{5}$ A detailed description of the different governance typologies is reported in the Appendixes.
} 
(Burkert et al., 2012). However, while this model of governance has been broadly used to understand the changes and shifts of power at the industry level, it has never been put in direct connection with operational practices adopted by buyers and suppliers in a SC. Because of this, the aim of this paper is to establish a connection between the different types of governance and the way in which the SC is managed thus extending the managerial potential of the GVC framework.

\section{Global value chains and SC management}

After discussing the GVC framework and its governance, we now explain the SC management practices considered in this study.

We focus on global SC management, which includes two fundamental areas: global sourcing and global distribution (Cagliano et al., 2008; Caniato et al., 2013; Meixell and Gargeya, 2005). Hence, in this study, we consider only the external SC and we do not include the manufacturing network (i.e., the network of plants that are part of the same group) as a part of the global SC. From the theoretical point of view, this is choice in line with the Global Value Chain literature which focuses on inter-firm relationships. Moreover, it helps to keep the analysis at a manageable level of complexity. However, the manufacturing network is definitely a relevant variable and it will be taken into account in the analysis as a contingent variable (together with company size).

The key decisions related to these two global sourcing and distribution are: 1) in which areas to seek for suppliers and customers (geographic dimension); 2) the type of relationship to establish with suppliers and customers (organizational dimension).

Regarding the geographic dimension, some authors (Cagliano et al., 2008; Caniato et al., 2013) highlighted that there are groups of companies that have globalized either sourcing or distribution but not both because the drivers for global sourcing (e.g., cost, access to resources) are very different from global distribution drivers (e.g., conquering new markets, following the customer) (Alguire et al., 1994; Vidal and Goetschalckx, 1997). Similarly, the risks involved in global sourcing and distribution can be very different (Christopher et al., 2011; Colicchia et al., 2010; Narasimhan and Talluri, 2009). In this discussion, however, the structure and geography of the entire GVC have 
seldom been considered. For instance, it could be the case that the suppliers and customers of certain products, are geographically concentrated in the same country as the focal company, thus not allowing for global sourcing or distribution.

Because of this situation, we expect that introducing a GVC perspective can provide further elements to help understand why companies do or do not perform global sourcing and distribution. In particular, our first research proposition is:

RP1. The GVC geography sets the context for the company to perform sourcing and distribution on a global scale.

For the second dimension of global SC management-i.e., how the relationships along the SC are managed - we refer to two main areas: technological collaboration, i.e., collaboration in the product development process (Dowlatshahi, 1998; Hartley et al., 1997; Petersen et al., 2006; Ren et al., 2015), and operational collaboration, i.e., integration in the production-logistics processes (Cagliano et al., 2006; Frohlich and Westbrook, 2001).

The first concept, technological collaboration in global SCs, is gaining increasing importance in the literature (Johnsen, 2009; Sturgeon et al., 2008). Although there is evidence that Information and Communication Technology and standardization (e.g., CAD/CAM systems) enable product development in collaboration with suppliers around the world, the need for tight collaboration (e.g., for high-complexity goods that are difficult to codify) still requires some degree of closeness (Salerno et al., 2009).

The second concept, operational collaboration, is usually analysed according to two dimensions: information sharing and physical system integration (Alfalla-Luque et al., 2013; Bartlett et al., 2007; Cagliano et al., 2003; Ruamsook et al., 2009; Vereecke and Muylle, 2006). First, companies have to exchange information (e.g., about production plans, inventories or market demand). This practice requires some standardization and integration of the ICT systems. However, the results are usually very beneficial for companies (e.g. Lee and Whang, 2000), for example, in helping to reduce the bullwhip effect (Lee et al., 1997). Information sharing has also been analysed in the specific context 
of global SCs, and the conclusion has been that it is vital for the effective flow of materials (Gunasekaran and Ngai, 2005; Lee and Whang, 2000). Next, the collaboration can move to the level of system integration, i.e., joint decision making and investments (e.g., just-in-time, vendor-managed inventory; collaborative planning forecasting and replenishment) (Meixell and Gargeya, 2005; Ovalle and Marquez, 2003). Since distance can be an obstacle to physical integration, the literature found that such investments have positive outcomes in global SCs only under specific conditions and company characteristics (Golini and Kalchschmidt, 2015a, 2015b).

The literature has already established a connection between the level of SC collaboration and network governance. Several authors (Choi and Kim, 2008; Cooper et al., 1997; Sherer, 2005) found information sharing as a key instrument and a tightening mechanism of network governance. Other authors (Grover and Malhotra, 2003; Hobbs, 1996; Nadvi, 2008; Williamson, 2008) relate governance to external determinants such as the transaction costs, suggesting that collaboration can be a feasible solution for high transaction costs. However, this type of analysis is generally limited to three situations: market-based relationships, collaboration and vertical integration.

Moreover, even in broad literature reviews such as the one by Pilbeam et al. (2012) we could not find a contribution that put in systematic connection external determinants of governance (as in the GVC framework) and SC management. Still, this can be a very useful contribution, since it would allow researchers and managers to analyse and define SC management strategies moving seamlessly from an industry perspective (GVC) to a firm perspective (SC management).

Given our focus on SC management, we excluded hierarchy (i.e., vertical integration) as a governance typology, and we considered "captive" to be the tightest typology of buyer-supplier governance.

With that in mind, in our paper we want to investigate the following propositions:

RP2. The closer to hierarchy the governance model with suppliers, the higher the level of SC collaboration, in terms of both operational and technological collaboration. 
RP3. The closer to hierarchy the governance model with customers, the higher the level of SC collaboration, in terms of both operational and technological collaboration.

Furthermore, the literature highlights a number of company-specific variables that can affect global SC management (e.g., Golini and Kalchschmidt, 2010; Kwon and Suh, 2004). In our paper, we consider two main factors: strategy and company size.

First, global SCs can be shaped according to different companies' competitive priorities. From the sourcing side, one of the most cited drivers for globalizing the supply chain is to reduce production costs (Alguire et al., 1994; Birou and Fawcett, 1993; Ettlie and Sethuraman, 2002; Frear et al., 1992; Trent and Monczka, 2003; Womack and Jones, 1996). The drawback to these potential advantages is an increased complexity that can increase transportation and inventory costs, procurement lead time and variability (Christopher et al., 2011; Meixell and Gargeya, 2005) and thus lead to lower responsiveness. As a consequence, for time-based competition companies, the geographic proximity of suppliers is still considered a key factor (Christopher et al., 2006; Demeter, 2013).

Since competitive priorities are often shared by the players along the supply chain (Fisher, 1997), we can assume that these dynamics also affect the relationship with customers and therefore:

RP4. Companies seeking high SC responsiveness (i.e., delivery time, product range and flexibility) tend to rely on domestic suppliers and have domestic customers.

RP5. Companies seeking low SC costs tend to rely on global suppliers and have global customers.

Finally, company size has been considered a major influencing factor. Larger companies can enjoy more resources and, in some cases, a multinational structure and this can help them to deploy more complex SC strategies (Brennan et al., 2015). For instance, sourcing globally can imply opening international purchasing offices (Jia et al., 2014), scouting new markets, managing new risks (Manuj, 2013) and, in general, developing new organizational capabilities (Zeng, 2003). As a consequence, multinational companies with production facilities abroad with some localization advantage (e.g., access to low cost inputs, skills or technologies) (Ferdows, 1997; Vereecke and Van Dierdonck, 2002) 
may use these outposts as sourcing centrals for the rest of the group (Jia et al., 2014; Sartor et al., 2015). From the distribution side, globalization requires opening foreign offices, addressing complex institutional factors (Bello et al., 2004) and developing new capabilities (Knight and Cavusgil, 2004; Weerawardena et al., 2007). As a consequence, despite the increasingly accessible global markets, smaller companies are generally more limited in their adoption of global SCs (Caniato et al., 2013; Leonidou, 1999; Quintens et al., 2005).

Moreover, size can alter the power distribution in the SC. Specifically, larger companies tend to take leading positions in the GVC (Humphrey, 2001), and thus, they have more power, resources and knowledge to coordinate the chain and develop some degree of SC integration with suppliers and customers (Stadtler, 2005).

In conclusion, our two final propositions are:

RP6. Company size is positively related to a higher share of global suppliers and customers.

RP7. Company size is positively related to a higher adoption of SC management collaboration practices with suppliers and customers.

\section{Methodology}

To investigate the abovementioned propositions, we focused on a specific industry, the electric motor industry. This decision was made considering that the GVC framework applies to a single industry at a time. Additionally, in the context of our aims, this industry shows interesting characteristics.

Electric motors constitute a large market and have relevant international flows (UNComtrade, $2005^{6}$ ). In 2005, Germany, Mexico and the United States were the 3 larger exporters of electric motors (Italy is seventh with 602 million US\$). The United States and Germany are also the two largest importers (Italy is fourth with US\$525 million). In Italy, where we interviewed companies, more than $60 \%$ of the exports are to Europe, but there are also significant exchanges with countries outside the continent

\footnotetext{
${ }^{6}$ http://comtrade.un.org/ This web site provides access to information and data on International Merchandise Trade Statistics (IMTS) and the work of the International Merchandise Trade Statistics Section (IMTSS) of the United Nations Statistics Division (UNSD).
} 
(e.g., the United States, China, Mexico). In terms of imports, Italy has a very strong relationship with Germany that accounts for $36 \%$ of its total imports. However, there are also significant exchanges with other European and non-European countries (e.g., the United States and China).

Electric motors are therefore a sector with a significant economic impact and a quite high degree of globalization, and this is also the case in Italy, where our case study companies were based. Therefore, it was reasonable to consider electric motors as a target industry for our case studies. Of course, there are specificities in this industry that will be taken into account during the analysis.

Furthermore, electric motors can be produced in different sizes with different target markets, but the upstream element of the SC (the suppliers and the production process) remains more or less the same for all of the players. Thus, there were some elements that changed and others that remained the same for all players, thus allowing for literal and theoretical replication when we analyzed the case studies (Meredith, 1998; Yin, 2009). Focusing on one single industry, we could study the global SC management practices of companies within the same GVC and thus discriminate between industryspecific and case-specific effects.

According to previous studies on the electric motor value chain (Lowe et al., 2010), four main stages can be identified (Figure A1 in the Appendixes):

1. Material and component production (steel, copper wire and bars, electrical components, permanent magnets, aluminium, spare parts, insulating materials, shaft, bearings);

2. Manufacturing and assembly of the electric motor;

3. System integration and installation (this stage is optional because the manufacturer can sell directly to the industrial user);

4. Industrial users, who can be divided into two groups. On one side, there are those who use the motor for process applications, meaning that the motor is used to run the machinery involved in the production process. On the other side, there are those who use the motor for product applications, meaning that the motor is part of the final product made by the customers (e.g., controlling motors for automobiles, gardening equipment, drills and white goods). 
Next, we focused on the lead firms in the chain (i.e., motor manufacturers), and we interviewed seven of them. As a matter of fact, the literature on GVC acknowledges the presence of lead firms as core actors in a segmented system of global economic governance (Ponte and Gibbon, 2005). As a consequence, our unit of analysis is the lead firm and its sets of relationships with suppliers and customers embedded in a specified GVC. The same unit of analysis can be found in the literature about competitiveness in GVCs (e.g., Buciuni and Mola, 2013; De Marchi et al., 2013).

We decided to adopt case studies given the nature of our study (i.e., bridging two different streams of literature) and the need to interpret the behavior of companies under the light of a very complex and rich context (i.e., the GVC and its governance). Case studies have been one of the most powerful research methods in operations management, especially for new theory development (Voss et al., 2002), but also, for extending or refining a theory, as in our case, especially when addressing strategic and complex topics (Boyer and McDermott, 1999; Pagell and Krause, 1999).

Following the practice described by Eisenhardt (1989) and Yin (2009), we selected cases according to different criteria, looking for theoretical and literal replication. Literal replication is the expectation that similar cases will produce similar results, and theoretical replication is the expectation that cases will provide different results but for predictable reasons. In our case, we selected companies of different sizes, with different global SC configurations, that produced motors with different characteristics.

In particular, we selected the companies according to two basic contingent variables: the size and the typology of the electric motors they manufactured (size of the motor, technology, applications). We interviewed one or two persons from each company who were responsible for SC activities (SC managers, purchasing managers, production managers and/or account managers). Two researchers participated in each interview, and for the majority of the cases, a plant visit followed and was integrated with the interview. Each interview lasted at least two hours and followed an interview protocol. The protocol was structured in the following sections (used to define the different constructs investigated in the study): 
1. General information about the company including turnover and number of employees (used to define company size);

2. Information about the product and the production process (used to identify the applications of the motor and the different components);

3. Competitive priorities and supply chain strategy (used in order to define the SC strategy)

4. Global sourcing strategy and supply management (used to define, for each component, the localization of suppliers, the typology of GVC governance and the relationship with suppliers);

5. Global distribution strategy and customer management (used to define the localization of customers, the typology of GVC governance and relationship with customers).

We opted to contact no additional cases after we had sufficient representativeness of different situations and the information added by each new case became marginal, in line with the theoretical saturation concept (Sandelowski, 1995). Since electric motors are always manufactured with the same components following very similar production phases, 7 cases were enough in order to have a good representation of all the typologies of suppliers and customers.

To have a clearer perspective of the SC and a complementary point of view, we also interviewed two suppliers of specific components (Table 1). For anonymity, we labelled each motor manufacturer according to its size (e.g., VS: very small, S: small) and the two suppliers as Su1 and Su2.

\section{TABLE 1 ABOUT HERE}

Each interview was recorded and then transcribed. The researchers then coded, with crossverification, the information collected. This was an iterative process with the objective of refining the coding at every step and highlighting the most relevant information and the differences among cases. This process led to the identification of different suppliers and customer categories (used in Table 3 and Figure 4). Finally, we contacted the companies again to complete any possible missing information, and we triangulated the collected data through secondary sources (economics databases and other publicly available information). 
After the information coding, we performed inter- and cross- case analyses.

\section{Results}

\section{GVC geographic structure and global SC processes (RP1)}

Our first research proposition states that the GVC geography sets the context for the company to perform sourcing and distribution on a global scale.

To investigate this proposition, we positioned the interviewed companies over the identified GVC (Figure 1). As explained before, we also interviewed two suppliers (Su1 and Su2) to obtain their perspectives on their relationships with the electric motor manufacturers. The first, Su1, supplied metal plates and pre-assembled rotors and stators. Su2 provided permanent magnets, importing them from China. We positioned them in the GVC as well.

\section{FIGURE 1 ABOUT HERE}

As shown in Figure 1, the different cases are positioned slightly differently in the GVC.

VS, S and M1 were focused only on motor manufacturing. M2 outsourced part of its motor production to Chinese suppliers, but the company integrated the motors with the fan systems and the hoods in-house. L1 was vertically integrated upstream, making its metal plates and shafts in-house. In this way, L1 could buy steel at the internationally set price on the stock market and produce internally with significant advantages on price and manufacturing reactivity. Finally, VL and L2 were able to make their motors and control systems in-house. In terms of global SC, this meant that they also had to interact with electronic component suppliers in the Far East.

As the GVC shows, among the inputs, there was a high share of raw materials and electronic components. These inputs were not manufactured in Italy. As a consequence, companies were required to either consider foreign suppliers or rely on local intermediaries (resellers, which can be considered as a form of local sourcing). Table 2 reports the average distribution of the value of the purchases (global sourcing) and sales (global distribution) outside the continent where the company 
was based (Europe in this case). The detail for each purchasing category is reported in Table A1 in the Appendixes.

\section{TABLE 2 ABOUT HERE}

The fact that companies had mixed strategies of global vs. local sourcing and different distribution strategies is in line with previous analyses in the manufacturing industry (Cagliano et al., 2008; Caniato et al., 2013).

In particular, VS and S purchased almost all materials domestically or within Europe. M1 showed a higher degree of globalization in that approximately $80 \%$ of its suppliers were still Italian, but the remaining 20\% were global (mainly the suppliers of copper, bearings, permanent magnets and other noncritical materials). For M2, about $50 \%$ of its purchases were global (mainly raw materials and a large share of finished motors). A similar situation held for L1, which sourced roughly $60 \%$ of its materials outside Europe (raw materials, bearings, some castings, other noncritical materials). On the contrary, L2 mainly sourced domestically ( $85 \%$ from domestic suppliers and 5\% from European supplier) and purchased roughly $10 \%$ of the materials (permanent magnets and some noncritical materials) globally. Finally, VL had the highest degrees of globalization, making about $50 \%$ of the purchases from outside of the country. As will be discussed later in the sections devoted to companyspecific factors, these differences depend mainly on the company size and strategy.

However, these different behaviours occurred within a context set by the GVC. Specifically, raw materials were produced by suppliers far away from Italy, so they needed to be either sourced globally or through intermediaries, while other inputs were available both globally and locally, thus leaving decisional space to the companies. These considerations allowed us to state that RP1 is supported for the upstream element of the SC.

With regard to downstream (i.e., distribution), the GVC shows us that there are two typologies of final markets, i.e. industrial process and product applications, while system integrators, i.e. the third type of direct customers, play the role of intermediaries between producers of electric motors and the final market. They all require quite customized products and some closeness between manufacturers and 
users. Because of this, many companies in our sample (VS, S, M1, M2 and L2) concentrated the majority of their sales in Italy and the remainder within Europe (Table 2). Only L1 and VL sold a significant share of their products globally. For these last two companies, however, an important role was played by their foreign sales units. From the customer perspective, sales units act as intermediaries, making the purchase more "local". Again, company size played an important role because only large companies distribute globally: this will be discussed later in the sections devoted to the company-specific factors. As in the upstream case, companies followed what already described by the literature on global distribution approaches (e.g., Katsikea and Skarmeas, 2003), however, the GVC increased our understanding of the strategies by showing a variety of customers and their global spread, thus leaving decisional space to companies.

These considerations allowed us to state that RP1 is also supported for the downstream part of the GVC.

\section{GVC governance and supply chain management (RP2-3)}

The second and third research propositions state that the governance model is related to the way the SC is managed in terms of operational and technological collaboration.

In order to assess the different forms of GVC governance used with suppliers, we applied the determinants as in Gereffi et al. (2005) (Table 3). For each component supplied we asked to the interviewees to classify into low, medium or high:

- the degree of customization of the component and difficulty to communicate the needs comparatively to the other components (used to measure the complexity of transaction);

- the possibility to use CAD drawings or standard specifications in the communication with suppliers (used to measure the ability to codify transactions);

- the availability and capability of suppliers comparatively to other components (used to measure the capabilities in the supply-base).

TABLE 3 ABOUT HERE 
Given the similarities in the type of components supplied, the answers were quite homogeneous and the final values reported in Table 3 were calculated as the average of the responses obtained for each case. On this basis, each component was classified into one of the following categories: raw materials, standard components, customized components and outsourced activities. As we can observe, raw materials and standard components were characterized by low complexity of transaction (i.e., it was easy for the buying firm to communicate its needs to the supplier), high ability to codify the transactions (i.e., communication was based on standard specifications) and high capabilities in the supply-base (i.e., there were many and capable suppliers). As a consequence, the type of governance assigned to these categories was market. Next, customized components showed a medium complexity of the transaction (i.e., it took time for the buying firm to communicate its needs), medium to high ability to codify the transaction and medium to high capabilities in the supply-base. It follows that the type of governance was modular/relational. Finally, outsourced activities were very customized (i.e., high complexity of the transaction) and the available suppliers were small and with limited capabilities. Hence the type of governance was relational/captive.

We used a similar logic to assess the typology of GVC governance used with customers. In this case, given the different target markets of the companies, the replies were more dispersed, thus requiring some analysis by the research team to identify the prevalent form of governance with a specific category of customers. This analysis suggested a modular/market type of governance with industrial users as the motor used in process applications was quite standard and there were many suppliers worldwide capable of supplying such product. On the contrary, system integrators and industrial users required very customized motors for which they needed suppliers with very high capabilities. As a consequence, the form of governance identified was relational. Naturally, there were discrepancies between the cases that have been addressed in the Company-specific behaviours section.

To investigate our research propositions, we put in relation the different forms of governance with the intensity of technological and operational collaboration with suppliers and customers. The detail is reported in Tables A2 and A3. We also analysed the levels of globalization for each relationship, i.e., to what extent suppliers or customers within a category were local or global. Notably, whereas 
technological collaboration can take place even in global networks (e.g., Eppringer and Chitkara, 2006), operational collaboration (e.g., just-in-time) may require some geographic proximity (Das and Handfield, 1997; Frazier et al., 1988).

Figure 2 sums up all the information. As previously explained, for each category of suppliers and customers we identified a specific form of governance. Next, for each form of governance, we reported the intensity (i.e., low, medium, high) of technological collaboration (TC), operational collaboration (OC) and globalization (G).

\section{FIGURE 2 ABOUT HERE}

The results are discussed in detail in the next paragraphs, beginning with sourcing (RP2) and continuing to distribution (RP3).

\section{Sourcing}

Raw materials (copper, steel and metal plates) represented roughly half of the total cost of an electric motor, and they fall in the category of market governance. A similar form governance with raw materials suppliers was in other industries by Gereffi et al. (2005) and Cagliano et al. (2003). Also suppliers of standard components (e.g., bearings) are managed through market governance. Given the presence of large multinational companies that specialize in raw materials and standard components production, and the fact that motor manufacturers seek cost savings, these suppliers' globalization levels are higher compared to the other categories. We found in the cases that when products are standard, it is easier to scout for suppliers abroad and this is aligned with the literature (Perona and Miragliotta, 2004; Westhead et al., 2001). In the case of copper, global sourcing is particularly easy to perform thanks to the existence of an international metal stock market, which is used by M1 and M2.

From the SC management point of view, given that these are standard products, no technological collaboration is needed. Operational collaboration is limited as well because these products are generally shipped from abroad in large batches. Indeed, very little information is exchanged except for what is necessary to complete the order. 
A similar situation holds for the standard components. All the companies, with the exception of VS, S and M2 buy permanent magnets and other non critical materials from global suppliers with a very low degree of interaction and collaboration.

A different situation is observed for customized components (metal castings, shafts and finished motors in the case of M2). In this case, the type of governance is a combination of modular and relational, confirming the findings of other studies (Caputo and Zirpoli, 2002; Sturgeon et al., 2008). The suppliers of customized components are typically located closer to the motor manufacturers (in Italy or Europe). Only VL and L1 use global sourcing for metal castings and none of the cases has global shaft suppliers. This is a function of the need for closer relationships with these suppliers to avoid the pitfalls of global sourcing (Christopher et al., 2011; Holweg et al., 2011). In fact, customization requires collaboration and trust because the suppliers often use customers' equipment (e.g., dies) (in line with Kwon and Suh, 2004). In contrast, it is worth noting that the problem of transportation costs is not relevant in selecting a local supplier even for large and heavy pieces (as stated by VL during the interview). Given the typology of components, technological collaboration is often needed. Especially at the initial stages (e.g., new product or new supplier), all the companies (except S) engage in some form of collaboration: co-design (VS, M1, M2) and co-location of design teams (L1, L2 VL) with the suppliers of customized components. After the supply relation has ben established, the suppliers work on specifications provided by the customer. It appears that it the beginning of the relationship the governance is more relational because of the higher difficulty to communicate the needs and slowly shits towards a modular one. Moreover, the level of operational collaboration with customized components suppliers is higher in terms of information exchanged and, in some cases, system integration. In fact, companies typically maintain low stocks of these components and thus they need their suppliers to be reactive. The operational collaboration ranges from informal and personal relationships (VS, S), to frame agreements and shared production plans (all the companies from M1 to VL), up to to shared forecasts (L1, VL) and Kanban systems (L1).

Finally, suppliers who perform outsourced activities help the companies with mechanical processing or performing windings. This type of governance is identified as a combination of relational and 
captive. This form of sourcing is not new and reminds the literature about subcontracting (Amesse et al., 2001) or captive outsourcing (e.g., Metters, 2008). However, in the latter, captive outsourcing refers to sourcing from owned plants (e.g., Hameri and Tunkelo, 2009); on the contrary, in our case, the company sources from external suppliers (in line with Gereffi et al., 2005). The similarity lies in the high level of control that the company exerts on its supply sources. Winding the stator or the rotor is a relatively simple process, but it is critical for the quality of the motor. Defective windings not only reduce the efficiency of the motor but, in many cases, compromise the functionality of the entire motor. Moreover, windings are one of the first production phases, and therefore they constitute a potential production bottleneck. Because of this, nearly all of the companies we interviewed perform windings entirely (L1, L2, VL) or partially (S, M1, M2) internally. The remainder is produced at local suppliers' facilities; this practice allowed even smaller companies to better control quality and gave them the necessary flexibility and reactivity. The level of technological collaboration was moderate and was limited to production processes at the supplier's. The level of operational collaboration was, however, very high, meaning that the suppliers and customers worked together to define shared production plans (M1, M2, L2).

In conclusion, we can see that the closer the relationship with suppliers is to captive, the higher the level of implementation of SC management practices, in terms of operational collaboration. For technological collaboration we found the maximum extent of adoption in the relational form, while in the captive form the level was moderate, coherently with the limited supplier capabilities. Thus, proposition 2 is only partially supported.

\section{Distribution}

Industrial process application users are supplied by manufacturers or system integrators, and they employ the motors in their production processes. For these users, the motor is part of a capital expenditure that is only made when a new facility or a motor replacement is necessary. In these contexts, also called build-to-order supply chains (Gunasekaran and Ngai, 2005), the buying company often employs more complex procurement processes and analyses, such as Total Cost of Ownership 
(Ferrin and Plank, 2002). Thus, it makes sense to treat this category of customers separately from the other.

The type of governance previously identified for this category of users was modular. The companies that worked with these customers were VS and VL and, to some extent, M1 and L1. We found that with this category of customers there was limited pressure on delivery lead times and motors were generally more standardized; thus, it was easier to sell them on a global scale with limited technological collaboration. Nevertheless, when the motors are extremely large (as in the case of VL), they are also partially customized, so that global sales units must be supported by local sales divisions that involve the customer in technological collaboration.

Next, the case of industrial product manufacturers (customers who employ the motor in their final products such as drills or fan coils) and system integrators is very different. In fact, for these companies, the motor is not a capital expenditure but a component to be designed and then regularly purchased from the suppliers. The type of governance identified was relational (high transaction complexity and capabilities in the supply base, but low ability to codify transactions). Cases S and M2 and, to some extent, M1 and L1 mainly had these types of customers. In this case, demand was generally more stable, and there was also a greater need to design the motor in collaboration with the customer, especially for innovative products. For instance, the European regulations developed in the last decade on household appliances in terms of energy saving and disposal, drove customers to work together with motor manufacturers to design smaller and eco-friendlier motors. The need for such close collaboration reduced customers' options for finding global suppliers and brought to long-term relationships that were consolidated by intense technological collaboration (in line with De Marchi, 2012). Moreover, the need to install the motors in the final product also required close operational collaboration in terms of information exchanged (for instance, production and delivery progress tracking and tracing, vendor-managed inventory and consignment stock). 
In conclusion, similar to what we found on the supplier side, the closer to relational the governance with customers, the more extensive the implementation of SC management practices, in terms of both operational and technological collaboration. Therefore, proposition 3 is supported.

\section{Company-specific behaviours}

Although the governance models did explain many of the decisions in terms of global SC management, the companies still showed some differences (Buciuni and Mola, 2013) (Figure 3).

\section{FIGURE 3 ABOUT HERE}

With customized components and outsourced activities, S and M1 tended to have long-term relationships with their suppliers, mainly to face demand uncertainty together. However, little additional information was exchanged (e.g., forecasts, production plans). For S and VS, these relationships were informal, whereas M1 used frame agreements of 3, 6 or 12 months with indexed prices. VL and L1 were instead more structured. In addition to frame agreements, VL exchanged 3-, 6- and 12-month forecasts with its key suppliers. For large orders, they also monitored the progress at the supplier's facility. L1 also put in place an electronic kanban system with its suppliers so that they could track the company's future needs and make weekly just-in-time deliveries.

Concerning raw materials, S and VS purchased from intermediaries; M1 and M2 procured raw copper on the London Metal Exchange; and VL and L1 directly negotiated with and set frame agreements with global suppliers. Additionally, VL and L1 engaged in more active risk management practices, through financial risk hedging on raw materials and retaining backup local suppliers in case of SC disruptions.

Finally, with regard to customers, L1 and VL had a more global market and different marketing and distribution systems that were supported by local sales units.

These relevant differences in the companies' behaviors can best be understood by adding in companyspecific factors such as competitive priorities and company size. 


\section{Company-specific factors: competitive priorities (RP4-5)}

Competitive priorities in a supply chain can be related to different performance dimensions that are considered as key to success (Shin et al., 2000). We classified competitive priorities into order winners and market qualifiers, following the definition by Hill (1993) (Table 4).

\section{Table 4 ABOUT HERE}

From Table 4, we can see that quality was a market qualifier for all the cases and this sometimes pushed companies to select known local suppliers. In fact, European motor manufacturers typically differentiate themselves by the higher quality of their products compared with those by the Chinese, who are their main competitors. However, especially for more standardized products, the motor's prices played an important role to qualify with customers .

For companies with a local SC (VS and S), the tight relationship with small local suppliers allowed them to be flexible in production (they generally produced small batches) and relatively quick with deliveries. In fact, the literature suggests that global sourcing can negatively affect lead times and flexibility (Christopher et al., 2011; Holweg et al., 2011). On the other side, the closeness with customers facilitated collaboration during product design. Nevertheless, these companies did not exploit this situation to implement SC management practices because their customers did not require them. Company L2, on the contrary, even if it is characterized by a local SC, does not consider flexibility a key factor, putting more attention on customization and after sales service, that can both benefit from a closer relationship with suppliers (Christopher et al., 2011; Holweg et al., 2011).

A similar situation occurs for the case of M1, which sold its products mainly in Europe but sourced locally. M1 had long-term relationships with a local supplier base, more formalized compared to the previous group, through frame agreements and contracts with prices indexed on the raw materials stock markets. In this way, they could be flexible and fast in production. They also sold outside of the country, maintaining a high level of customization because of their established direct relationships with customers abroad. However, this was easier because their customers were mainly located in 
Europe; M1 confirmed that their practices would have been more difficult if their customers had been in other continents.

M2, which performed global sourcing, was less in touch with its suppliers, but tended to have longterm relationships formalized through frame agreements. They also had frame agreements with customers who were mainly domestic. In fact, M2 was focused on after sales service and customization, which was made easier by their closeness with their customers, an observation that M2 highlighted.

Finally, companies with global SCs (L1 and VL) differentiated themselves particularly through global customization and after-sales services. They were able to support this through their local sales units. Because they competed internationally, these companies were also the most careful about costs, which drove them to expand their global sourcing and manufacturing to exploit cost advantages on a global scale (in line with Alguire et al., 1994).

We can summarize our results on companies that attempted to maintain responsive (VS, S, M1) or efficient (L1, L2, VL, M2) SCs, in line with (Fisher, 1997). Although the companies in both groups used operational collaboration to increase either responsiveness or efficiency, the main difference among the two groups was the localization of their suppliers.

In conclusion, propositions 4 and 5 are supported.

\section{Company-specific factors: company size (RP6-7)}

Moving to company characteristics, size was by far the primary factor that explained the differences among cases.

Smaller companies (S, VS) for the most part had very limited global sourcing and distribution and no global manufacturing in place. This is in line with the literature (Cagliano et al., 2008; Cavusgil, 1980; Lee and Whang, 2000; Quintens et al., 2005), but thanks to the cases, we can provide additional evidence to the phenomenon. For purchases that had to be made abroad (e.g., copper and steel), they typically relied on intermediaries. They also generally did not have the bargaining power to influence 
large suppliers or customers to implement SC integration. They competed strongly on speed, flexibility and customization (especially VS). Because of these factors, these companies required fast, reliable, known suppliers. The weaknesses of this strategy were: missing out on some of the opportunities offered by globalization (such as cheap supplies of standard materials, access to new markets); exposure to upstream raw material price fluctuations; and reliance on a small number of large customers who controlled access to the market.

The medium companies (M1 and M2) instead had more developed global SCs. They purchased their raw materials on the London Metal Exchange, and obtained other components (e.g., bearings, spare parts) globally. M2 also purchased some of its motors from China. Their market was more international but mainly at the European level.

L1 was considerably more global in terms of sourcing and distribution. Because of its size, L1 was also able to put in place an electronic kanban system with their suppliers, thus making deliveries faster and reducing inventories by $30 \%$. Additionally, its market was quite global but was supported by local sales units.

In contrast, L2 was quite local. The company was relatively large (more than 300 employees), and in the past, they had worked directly with global suppliers; and they had also attempted to adopt operational integration with their suppliers, such as just-in-time production. However, according to the managers, the size of their business did not justify the adoption of such practices, and thus they returned to relying on local suppliers or intermediaries and limiting their operational collaboration to frame agreements.

Finally, VL was a truly global company with several plants around the world. Some of these plants (e.g., the one in India) supplied other plants with parts of the finished product. They extensively used global corporate agreements to procure standardized goods such as steel that would then be sent to external suppliers for processing. Even though their level of global purchasing was still relatively low (roughly $20 \%$ ), their aim was to increase it while always retaining local backup suppliers. As in the case of L1, VL sold through local commercial units. 
To conclude this analysis, we can see how larger companies have more possibilities to seek suppliers and customers abroad and to push the adoption of formal operational collaboration, although this opportunity is not always exploited, as in the case of L2.

In conclusion, the propositions 6 and 7 are supported.

\section{Conclusions and further developments}

The Global Value Chain (GVC) analysis is being increasingly advocated as a powerful tool for interpreting managerial issues, with particular reference to global SC management (Gereffi and Lee, 2012). However, there is still a gap in how to apply at the company level the GVC concepts that have been developed at the industry level. Through our field data, we attempted to partly fill this gap by establishing a connection between the GVC framework and SC management.

The framework emerging from our results is reported in Figure 4.

\section{FIGURE 4 ABOUT HERE}

First, we showed how the GVC can be a useful framework for understanding and explaining the global SC strategies (in terms of degree of global sourcing and distribution) implemented at the company level. As discussed in the results sections, companies tend to follow the behaviours described by the literature for what concerns global sourcing (e.g., Christopher et al., 2011; Trent and Monczka, 2002, 2003) and distribution (e.g., Katsikea and Skarmeas, 2003). However, these behaviours are constrained by the input/output and geographical structure of the GVC. Therefore, this paper highlights the importance for both researchers and practitioners to support the analysis of global SC strategies by means of a GVC map (represented by the RP1 arrow in Figure 4). Furthermore, we found market, modular and relational governance to be related to increasing levels of collaboration (both operational and technological) (represented by the RP2-3 arrow in Figure 4). Captive governance is instead quite different, as it implies a change in the power balance (in favour of the buyer), so, in future studies, we suggest considering it separately. 
Furthermore, the GVC governance typologies appeared to be directly related to the globalization levels of certain branches of the value chain (i.e., whether the company relied on local or global suppliers or customers) and the degree of technological (i.e., product development) and operational (i.e., information sharing and system integration) collaboration. In particular, when there is a choice between local and global suppliers, the closer to relational the governance, the higher the likelihood that the company would rely on local suppliers with a high level of operational collaboration and vice versa (represented by the dotted line in Figure 4). This is in line with previous papers (Das et al., 2006; Kotabe and Murray, 2004; Kraljic, 1983) that suggest that global sourcing and SC collaboration are not always the best strategies and they may even result in trade-off with each other. The adoption of such strategies should be balanced and differentiated for specific purchasing categories by evaluating performance metrics and strategic capabilities of suppliers (Talluri and Narasimhan, 2004).

Moreover, we found the maximum extent of technological collaboration in the relational governance model, where the buyer and the supplier are both capable firms and they share their knowledge for the development of new products (e.g., the development of more energy efficient motors with industrial product application customers). On the contrary, in the case of captive governance, the level of collaboration was lower. These results suggest that the design of a global SC is a complex process that starts from the input/output and geographical structure, but then becomes an iterative process to determine the typology of governance, extent of collaboration and location of suppliers and customers.

In this decision making process, we showed the importance of considering two company-specific factors: size and competitive priorities. Large and small companies with different competitive priorities coexist in the same GVC. In particular, larger companies seem to have greater freedom in deciding on the level of globalization and the degree of collaboration even within the same governance structure (RP6-7 arrow in Figure 4). This seems in line with previous studies highlighting the potential benefits of a joint adoption of global sourcing and collaboration with suppliers (Golini and Kalchschmidt, 2011; Murray, 2001). However, from our cases, such approach seems to be available only for larger companies. It is important to underline that, although the GVC provides some 
constraints and opportunities, the single firm is still free to decide its own strategy within such constraints (e.g., sourcing locally even if global suppliers are available, or use intermediaries), on the base of its own characteristics and capabilities. Moreover, large companies with an international manufacturing network should also evaluate how different decisions on the manufacturing network can impact the GVC. For example, such companies may decide to invest in a manufacturing plant located in a specific area in order to reach a more relational form governance with local suppliers and customers.

Competitive priorities also played an important role: companies that based their competitiveness on a responsive SC tended to use more local suppliers than companies competing on an efficient SC (RP67 Arrow in Figure 4). This represent an important contribution for GVC scholars which have seldom included SC strategy as a driver for differences in the structure and governance of the GVC (Burkert et al., 2012).

In conclusion, the GVC framework appears to be an effective tool to be further tested and developed by SC management scholars. In particular, the GVC stimulates a strategic overview of the entire SC (from raw materials to customers) and offers a continuum of governance typologies (from market to hierarchy) determined by a small number of key factors. These typologies appeared to be very effective in explaining the majority of behaviours related to SC globalization and collaboration that were not company-specific. This work provides evidence that the GVC framework can integrate different characteristics of complex supply networks and can help in putting together different methodological perspectives, from the strategic to the operational one. However, using the GVC should be accompanied by a more specific analysis of a company's characteristics (i.e., size and competitive priorities) to provide clearer managerial insights.

In addition, the GVC framework is quite simple and flexible to different visual representations (e.g., Figure 1) making it well understandable by practitioners. During our case studies we always started by displaying the GVC to the interviewed managers and that helped to have a common framework for the discussion. Moreover, as the value chain concept is tightly related to the company strategy, the 
GVC framework can help companies to align their business strategy with the SC management and overcome two issues that are considered critical for the achievement of higher performance: strategy execution in the SC (Khadem, 2008; Kotzab et al., 2011) and the identification of the most effective forms of governance (Provan and Kenis, 2008). In particular, our framework can help to address the managerial trade-offs that make the decisions related to global supply chains very complex.

What we found is that large companies aiming at being efficient look for global suppliers even if this can limit the extent of collaboration. These companies also have local suppliers managed through captive forms of governance, mainly to have external production capacity available. On the other side, small companies or large companies with a responsive strategy, establish relational forms of governance by leveraging local supply sources and collaboration with SC partners. However, if the local supply base does not have the necessary capabilities, there is the risk to slip into a captive form of governance where the lead firm has to guide the suppliers instead of receiving support from them.

Of course, this study is not free from limitations. First of all, we focused on a single industry, however, the electric motor industry has a number of features that make our results likely to be generalizable to other industries. First, there is a variety of inputs (raw materials, standard and customized components, outsourced activities), products and markets. Next, the value chain is quite global in terms of the fragmentation and geographical dispersion of the activities, but there is still the possibility for companies to source domestically. Finally, the types of product and production make these results theoretically applicable to any other assembly manufacturing industry. In fact, international studies on SCs in assembly manufacturing industries do not generally find significant differences in terms of sub-industries (Strader et al., 1999; Vargas et al., 2000; Vereecke and Muylle, 2006). The generalizability of our findings is also witnessed by the fact that, as discussed in the results, we have found different typologies of governance modes that are consistent with what was found by other studies in different industries.

Another important aspect is that our study was conducted in Italy, and therefore, these companies were particularly exposed to competition from low-cost countries, especially China. However, this 
situation is similar for companies in other mature countries, as was confirmed by the managers of VL, a genuinely multinational company. However, future studies could attempt to include other countries to replicate and extend the results identified so far.

Furthermore, we did not focus on the design of the global manufacturing network and, more in general, hierarchical forms of governance. We were specifically interested in inter-firm relationships in the SC and the decision to limit our focus and exclude the internal network is justified by the limited exchanges of goods among plants of the same company. However, future works could extend our results and develop a higher-level framework that also includes make-or-buy and production location decisions in the context of SC strategy.

In terms of future developments, even though this avenue was not pursued in this study, the GVC framework also suggests different patterns of upgrading that firms could pursue to enhance their competitiveness (Humphrey, 2003; Humphrey and Schmitz, 2000). Future studies could investigate how such upgrading patterns affect the relationships in the SC and can be supported by SC management programs. Moreover, given the increasing importance of risk management and sustainability in global SCs, future works could try to verify how such concepts can affect either the governance or the global SC management modes. Finally, as SC management can influence both buyer and supplier performance (Shin et al., 2000), a step forward should be made by looking at how the alignment between GVC governance and SC management affects the performance of all the parties involved.

\section{References}

Abecassis-Moedas, C., 2006. Integrating design and retail in the clothing value chain: An empirical study of the organisation of design. International Journal of Operations \& Production Management 26 (4), 412-428.

Alfalla-Luque, R., Medina-Lopez, C., Dey, P.K., 2013. Supply chain integration framework using literature review. Production Planning \& Control 24 (8-9), 800-817.

Alguire, M.S., Frear, C.R., Metcalf, L.E., 1994. An examination of the determinants of global sourcing strategy. Journal of Business \& Industrial Marketing 9 (2), 62-74.

Amesse, F., Dragoste, L., Nollet, J., Ponce, S., 2001. Issues on partnering: evidences from subcontracting in aeronautics. Technovation 21 (9), 559-569.

Aulakh, P.S., Gencturk, E.F., 2000. International principal-agent relationships: control, governance and performance. Industrial Marketing Management 29 (6), 521-538. 
Bartlett, P.A., Julien, D.M., Baines, T.S., 2007. Improving supply chain performance through improved visibility. International Journal of Logistics Management 18 (2), 294-313.

Bello, D.C., Lohtia, R., Sangtani, V., 2004. An institutional analysis of supply chain innovations in global marketing channels. Industrial Marketing Management 33 (1), 57-64.

Birou, L.M., Fawcett, S.E., 1993. International purchasing: Benefits, requirements, and challenges. Journal of Supply Chain Management 29 (2), 27-37.

Boyer, K.K., McDermott, C., 1999. Strategic consensus in operations strategy. Journal of Operations Management 17 (3), 289-305.

Brennan, L., Ferdows, K., Godsell, J., Golini, R., Keegan, R., Kinkel, S., Srai, J.S., Taylor, M., 2015. Manufacturing in the world: where next? International Journal of Operations \& Production Management 35 (9), 1253 - 1274.

Buciuni, G., Mola, L., 2013. How do entrepreneurial firms establish cross-border relationships? A global value chain perspective. Journal of International Entrepreneurship 12 (1), 67-84.

Burkert, M., Ivens, B.S., Shan, J., 2012. Governance mechanisms in domestic and international buyer-supplier relationships: An empirical study. Industrial Marketing Management 41 (3), 544-556.

Cagliano, R., Caniato, F., Golini, R., Kalchschmidt, M., Spina, G., 2008. Supply chain configurations in a global environment: A longitudinal perspective. Operations Management Research 1 (2), 86-94.

Cagliano, R., Caniato, F., Spina, G., 2003. E-business strategy: how companies are shaping their supply chain through the internet. International Journal of Operations \& Production Management 23 (10), 1142-1162.

Cagliano, R., Caniato, F., Spina, G., 2006. The linkage between supply chain integration and manufacturing improvement programmes. International Journal of Operations \& Production Management 26 (3), 282-299.

Caniato, F., Golini, R., Kalchschmidt, M., 2013. The effect of global supply chain configuration on the relationship between supply chain improvement programs and performance. International Journal of Production Economics 143 (2), 285-293.

Caputo, M., Zirpoli, F., 2002. Supplier involvement in automotive component design: outsourcing strategies and supply chain management. International Journal of Technology Management 23 (1), 129-159.

Caridi, M., Crippa, L., Perego, A., Sianesi, A., Tumino, A., 2009. Do virtuality and complexity affect supply chain visibility? International Journal of Production Economics 127 (2), 372-383.

Cavusgil, S.T., 1980. On the internationalization process of firms. European Research 8 (6), 273-281.

Chiarvesio, M., Di Maria, E., 2009. Internationalization of supply networks inside and outside clusters. International Journal of Operations \& Production Management 29 (11), 1186-1207.

Choi, T., Kim, Y., 2008. Triads in supply networks: theorizing buyer-supplier-supplier relationships. Journal of Supply Chain Management 24 (5), 637-652.

Christopher, M., Mena, C., Khan, O., Yurt, O., 2011. Approaches to managing global sourcing risk. Supply Chain Management: An International Journal 16 (2), 67-81.

Christopher, M., Peck, H., Towill, D., 2006. A taxonomy for selecting global supply chain strategies. International Journal of Logistics Management 17 (2), 277-287.

Claro, D.P., Hagelaar, G., Omta, O., 2003. The determinants of relational governance and performance: how to manage business relationships? Industrial Marketing Management 32 (8), 703716.

Colicchia, C., Dallari, F., Melacini, M., 2010. Increasing supply chain resilience in a global sourcing context. Production planning \& control 21 (7), 680-694.

Cooper, M.C., Lambert, D.M., Pagh, J.D., 1997. Supply chain management: more than a new name for logistics. International Journal of Logistics Management, The 8 (1), 1-14.

Das, A., Handfield, R.B., 1997. Just-in-time and logistics in global sourcing: an empirical study. Management 27 (3/4), 244-259.

Das, A., Narasimhan, R., Talluri, S., 2006. Supplier integration-finding an optimal configuration. Journal of Operations Management 24 (5), 563-582.

De Marchi, V., 2012. Environmental innovation and R\&D cooperation: Empirical evidence from Spanish manufacturing firms. Research Policy 41 (3), 614-623.

De Marchi, V., Maria, E.D., Micelli, S., 2013. Environmental strategies, upgrading and competitive advantage in global value chains. Business Strategy and the Environment 22 (1), 62-72. 
Demeter, K., 2013. Time-based competition - the aspect of partner proximity. Decision Support Systems 54 (4), 1533-1540.

Dornier, P.P., Ernst, R., Fender, M., Kouvelis, P., 2008. Global operations and logistics: Text and cases. Wiley, United States of America.

Dowlatshahi, S., 1998. Implementing early supplier involvement: a conceptual framework. International Journal of Operations \& Production Management 18 (2), 143-167.

Eisenhardt, K.M., 1989. Building theories from case study research. Academy of management review 14 (4), 532-550.

Eppringer, S., Chitkara, A.R., 2006. The practice of global product development. MIT Sloan Management Review 47 (4), 22-30.

Ettlie, J.E., Sethuraman, K., 2002. Locus of supply and global manufacturing. International Journal of Operations \& Production Management 22 (3), 349-370.

Ferdows, K., 1997. Making the most of foreign factories. Harvard Business Review 75, 73-91.

Ferrin, B.G., Plank, R.E., 2002. Total cost of ownership models: An exploratory study. Journal of Supply chain management 38 (2), 18-29.

Fisher, M.L., 1997. What is the right supply chain for your product? Harvard Business Review 75, 105-117.

Fleury, A., 1999. The changing pattern of operations management in developing countries: the case of Brazil. International Journal of Operations \& Production Management 19 (5/6), 552-564.

Frazier, G.L., Spekman, R.E., O'Neal, C.R., 1988. Just-in-time exchange relationships in industrial markets. The Journal of Marketing, 52-67.

Frear, C.R., Metcalf, L.E., Alguire, M.S., 1992. Offshore sourcing: its nature and scope. International Journal of Purchasing and Materials Management 28 (3), 2-11.

Frohlich, M.T., Westbrook, R., 2001. Arcs of integration: An international study of supply chain strategies. Journal of Operations Management 19 (2), 185-200.

Gereffi, G., 1994. The organization of buyer-driven global commodity chains: how US retailers shape overseas production networks, in: Gereffi, G., Korzeniewicz, M. (Eds.), Commodity Chains and Global Capitalism. Praeger Publishers, Westport, UK, pp. 95-122.

Gereffi, G., Humphrey, J., Kaplinsky, R., 2001. Introduction: Globalisation, value chains and development. IDS bulletin 32 (3), 1-8.

Gereffi, G., Humphrey, J., Sturgeon, T., 2005. The governance of global value chains. Review of international political economy 12 (1), 78-104.

Gereffi, G., Lee, J., 2012. Why the world suddenly cares about global supply chains. Journal of Supply Chain Management 48 (3), 24-32.

Gibbon, P., 2001. Upgrading primary production: a global commodity chain approach. World Development 29 (2), 345-363.

Giuliani, E., Pietrobelli, C., Rabellotti, R., 2005. Upgrading in global value chains: lessons from Latin American clusters. World development 33 (4), 549-573.

Golini, R., Kalchschmidt, M., 2010. Global Supply Chain Management and delivery performance: a contingent perspective, in: Gerald, R. (Ed.), Rapid modelling and quick response - intersection of theory and practice. Springer, London, pp. 231-247.

Golini, R., Kalchschmidt, M., 2011. Moderating the impact of global sourcing on inventories through supply chain management. International Journal of Production Economics 133 (1), 86-94.

Golini, R., Kalchschmidt, M., 2015a. Designing an expert system to support competitiveness through global sourcing. International Journal of Production Research 53 (13), 3836-3855.

Golini, R., Kalchschmidt, M., 2015b. Managing inventories in global sourcing contexts: A contingency perspective. International Journal of Production Economics 165, 64-78.

Grandori, A., Soda, G., 1995. Inter-firm networks: antecedents, mechanisms and forms. Organization studies 16 (2), 183-214.

Grover, V., Malhotra, M.K., 2003. Transaction cost framework in operations and supply chain management research: theory and measurement. Journal of Operations management 21 (4), 457-473.

Gunasekaran, A., Ngai, E.W.T., 2005. Build-to-order supply chain management: a literature review and framework for development. Journal of Operations Management 23 (5), 423-451.

Hameri, A.-P., Tunkelo, T., 2009. Captive outsourcing-a way to move complex products to emerging markets. Strategic Outsourcing: An International Journal 2 (1), 54-67. 
Handfield, R.B., 1994. US global sourcing: patterns of development. International Journal of Operations \& Production Management 14 (6), 40-51.

Hartley, J.L., Zirger, B.J., Kamath, R.R., 1997. Managing the buyer-supplier interface for on-time performance in product development. Journal of Operations Management 15 (1), 57-70.

Hernández-Espallardo, M., Rodríguez-Orejuela, A., Sánchez-Pérez, M., 2010. Inter-organizational governance, learning and performance in supply chains. Supply Chain Management: An International Journal 15 (2), 101-114.

Hill, T., 1993. Manufacturing strategy: the strategic management of the manufacturing function. Macmillan, London (UK).

Hobbs, J.E., 1996. A transaction cost approach to supply chain management. Supply Chain Management: An International Journal 1 (2), 15-27.

Holweg, M., Reichhart, A., Hong, E., 2011. On risk and cost in global sourcing. International Journal of Production Economics 131 (1), 333-341.

Humphrey, J., 2001. Governance in global value chains. IDS bulletin 32 (3), 19-29.

Humphrey, J., 2003. Opportunities for SMEs in Developing Countries to Upgrade in a Global Economy, InFocus Programme on Boosting Employment through Small Enterprise Development, Job Creation and Enterprise Development, International Labour Office, Geneva.

Humphrey, J., Schmitz, H., 2000. Governance and upgrading: linking industrial cluster and global value chain research. Institute of Development Studies Brighton.

Jia, F., Lamming, R., Sartor, M., Orzes, G., Nassimbeni, G., 2014. Global purchasing strategy and International Purchasing Offices: Evidence from case studies. International Journal of Production Economics 154, 285-298.

Johnsen, T.E., 2009. Supplier involvement in new product development and innovation: Taking stock and looking to the future. Journal of Purchasing and Supply Management 15 (3), 187-197.

Katsikea, E.S., Skarmeas, D.A., 2003. Organisational and managerial drivers of effective export sales organisations: An empirical investigation. European Journal of Marketing 37 (11/12), 1723-1745.

Khadem, R., 2008. Alignment and follow-up: steps to strategy execution. Journal of Business Strategy 29 (6), 29-35.

Knight, G.A., Cavusgil, S.T., 2004. Innovation, organizational capabilities, and the born-global firm. Journal of International Business Studies 35 (2), 124-141.

Kotabe, M., Murray, J.Y., 2004. Global sourcing strategy and sustainable competitive advantage. Industrial Marketing Management 33 (1), 7-14.

Kotzab, H., Teller, C., Grant, D.B., Sparks, L., 2011. Antecedents for the adoption and execution of supply chain management. Supply Chain Management: An International Journal 16 (4), 231-245.

Kraljic, P., 1983. Purchasing must become supply management. Harvard Business Review 61 (5), 109-117.

Kwon, I.W.G., Suh, T., 2004. Factors affecting the level of trust and commitment in supply chain relationships. Journal of Supply Chain Management 40 (2), 4-14.

Lee, H.L., Padmanabhan, V., Whang, S., 1997. Information distortion in a supply chain: the bullwhip effect. Management science 43 (4), 546-558.

Lee, H.L., Whang, S., 2000. Information sharing in a supply chain. International Journal of Manufacturing Technology and Management 1 (1), 79-93.

Lee, J., 2010. Global commodity chains and global value chains. The International Studies Encyclopedia. Oxford: Wiley-Blackwell, 2987-3006.

Leonidou, C., 1999. Barriers to international purchasing: the relevance of firm characteristics. International Business Review 8 (4), 487-512.

Lowe, M., Golini, R., Gereffi, G., 2010. US Adoption of High-Efficiency Motors and Drives: Lessons Learned, Report prepared for the Environmental Defense Fund (EDF). Center on Globalization, Governance and Competitiveness.

MacCarthy, B.L., Atthirawong, W., 2003. Factors affecting location decisions in international operations a Delphi study. International Journal of Operations \& Production Management 23 (7/8), 794-819.

Manuj, I., 2013. Risk Management in Global Sourcing. Transportation Journal 52 (1), 80-107.

Manuj, I., Mentzer, J.T., 2008. Global supply chain risk management. Journal of Business logistics 29 (1), 133-155. 
Meixell, M.J., Gargeya, V.B., 2005. Global supply chain design: A literature review and critique. Transportation Research 41 (6), 531-550.

Meredith, J., 1998. Building operations management theory through case and field research. Journal of Operations Management 16 (4), 441-454.

Metters, R., 2008. A typology of offshoring and outsourcing in electronically transmitted services. Journal of Operations Management 26 (2), 198-211.

Motwani, J., Larson, L., Ahuja, S., 1998. Managing a global supply chain partnership. Logistics Information Management 11 (6), 349-354.

Murray, J.Y., 2001. Strategic alliance-based global sourcing strategy for competitive advantage: A conceptual framework and research propositions. Journal of International Marketing 9 (4), 30-58.

Nadvi, K., 2008. Global standards, global governance and the organization of global value chains. Journal of Economic Geography 8 (3), 323-343.

Narasimhan, R., Talluri, S., 2009. Perspectives on risk management in supply chains. Journal of Operations Management 27 (2), 114-118.

Ovalle, R.O., Marquez, C.A., 2003. The effectiveness of using e-collaboration tools in the supply chain: an assessment study with system dynamics. Journal of Purchasing and Supply Management 9 (4), 151-163.

Pagell, M., Krause, D.R., 1999. A multiple-method study of environmental uncertainty and manufacturing flexibility. Journal of Operations Management 17 (3), 307-325.

Perona, M., Miragliotta, G., 2004. Complexity management and supply chain performance assessment. A field study and a conceptual framework. International Journal of Production Economics 90 (1), 103-115.

Petersen, K.J., Prayer, D.J., Scannell, T.V., 2006. An empirical investigation of global sourcing strategy effectiveness. Journal of Supply Chain Management 36 (2), 29-38.

Pilbeam, C., Alvarez, G., Wilson, H., 2012. The governance of supply networks: a systematic literature review. Supply Chain Management: An International Journal 17 (4), 358-376.

Ponte, S., Gibbon, P., 2005. Quality standards, conventions and the governance of global value chains. Economy and society 34 (1), 1-31.

Prasad, S., Babbar, S., 2000. International operations management research. Journal of operations management 18 (2), 209.

Provan, K.G., Kenis, P., 2008. Modes of network governance: Structure, management, and effectiveness. Journal of public administration research and theory 18 (2), 229-252.

Quintens, L., Matthyssens, P., Faes, W., 2005. Purchasing internationalisation on both sides of the Atlantic. Journal of Purchasing and Supply Management 11 (2-3), 57-71.

Ren, S.J., Hu, C., Ngai, E.W.T., Zhou, M., 2015. An empirical analysis of inter-organisational value co-creation in a supply chain: a process perspective. Production Planning \& Control (ahead-of-print), $1-12$.

Ruamsook, K., Russell, D.M., Thomchick, E.A., 2009. Sourcing from low-cost countries: Identifying sourcing issues and prioritizing impacts on logistics performance. International Journal of Logistics Management 20 (1), 79-96.

Salerno, M.S., Marx, R., Zilbovicius, M., Dias, A.V.C., 2009. The importance of locally commanded design for the consolidation of local supply chain: the concept of design headquarters. International Journal of Manufacturing Technology and Management 16 (4), 361-376.

Sandelowski, M., 1995. Sample size in qualitative research. Research in nursing \& health 18 (2), 179183.

Sartor, M., Orzes, G., Nassimbeni, G., Jia, F., Lamming, R., 2015. International purchasing offices in China: roles and resource/capability requirements. International Journal of Operations \& Production Management 35 (8), 1125-1157.

Sherer, S.A., 2005. From supply-chain management to value network advocacy: implications for esupply chains. Supply Chain Management: An International Journal 10 (2), 77-83.

Shin, H., Collier, D.A., Wilson, D.D., 2000. Supply management orientation and supplier/buyer performance. Journal of operations management 18 (3), 317-333.

Stadtler, H., 2005. Supply Chain Management - An Overview. Springer Berlin (Germany). 
Stank, T.P., Dittmann, J.P., Autry, C.W., 2011. The new supply chain agenda: a synopsis and directions for future research. International Journal of Physical Distribution \& Logistics Management $41(10), 940-955$.

Stock, J.R., Boyer, S.L., Harmon, T., 2010. Research opportunities in supply chain management. Journal of the Academy of Marketing Science 38 (1), 32-41.

Strader, T.J., Lin, F.-R., Shaw, M.J., 1999. Business-to-business electronic commerce and convergent assembly supply chain management. Journal of Information Technology 14 (4), 361-373.

Sturgeon, T., Van Biesebroeck, J., Gereffi, G., 2008. Value chains, networks and clusters: reframing the global automotive industry. Journal of economic geography 8 (3), 297-321.

Sturgeon, T.J., 2002. Modular production networks: a new American model of industrial organization. Industrial and corporate change 11 (3), 451-496.

Talluri, S., Narasimhan, R., 2004. A methodology for strategic sourcing. European journal of operational research 154 (1), 236-250.

Trent, R.J., Monczka, R.M., 2002. Pursuing competitive advantage through integrated global sourcing. The Academy of Management Executive (1993-2005), 66-80.

Trent, R.J., Monczka, R.M., 2003. Understanding integrated global sourcing. International Journal of Physical Distribution \& Logistics Management 33 (7), 607-629.

UNCTAD, 2010. Integrating Developing Countries' SMEs into Global Value Chains United Nations Conference on Trade and Development.

UNCTAD, 2013. World Investment Report - Global Value Chains: Investment and Trade for Development.

Vargas, G., Cardenas, L., Matarranz, J.L., 2000. Internal and external integration of assembly manufacturing activities. International Journal of Operations \& Production Management 20 (7), 809822.

Vereecke, A., Muylle, S., 2006. Performance improvement through supply chain collaboration in Europe. International Journal of Operations \& Production Management 26 (11), 1176-1198.

Vereecke, A., Van Dierdonck, R., 2002. The strategic role of the plant: testing Ferdows's model. International Journal of Operations \& Production Management 22 (5/6), 492-514.

Vidal, C.J., Goetschalckx, M., 1997. Strategic production-distribution models: A critical review with emphasis on global supply chain models. European Journal of Operational Research 98 (1), 1-18.

Voss, C., Tsikriktsis, N., Frohlich, M., 2002. Case research in operations management. International Journal of Operations \& Production Management 22 (2), 195-219.

Weerawardena, J., Mort, G.S., Liesch, P.W., Knight, G., 2007. Conceptualizing accelerated internationalization in the born global firm: A dynamic capabilities perspective. Journal of World Business 42 (3), 294-306.

Westhead, P., Wright, M., Ucbasaran, D., 2001. The internationalization of new and small firms:: A resource-based view. Journal of Business Venturing 16 (4), 333-358.

Williamson, O.E., 2008. Outsourcing: Transaction Cost Economics and Supply Chain Management. Journal of supply chain management 44 (2), 5-16.

Womack, J.P., Jones, D., 1996. Lean thinking: banish waste and create wealth in your corporation. Free Press, New York (US).

World Economic Forum, 2012. The Shifting Geography of Global Value Chains: Implications for Developing Countries and Trade Policy.

Yin, R.K., 2009. Case study research: Design and methods. Sage Publications, Inc, Thousands Oaks, USA.

Yu, C.-M.J., Liao, T.-J., Lin, Z.-D., 2006. Formal governance mechanisms, relational governance mechanisms, and transaction-specific investments in supplier-manufacturer relationships. Industrial Marketing Management 35 (2), 128-139.

Zeng, A.Z., 2003. Global sourcing: process and design for efficient management. Supply Chain Management: An International Journal 8 (4), 367-379. 


\section{Appendixes}

\section{Definition of different governance typologies}

Following the definitions of Gereffi and Lee (2012):

- Market governance involves transactions that are relatively simple. Suppliers can make products with minimal input from and little coordination with buyers. Price is the central governance mechanism in the arm's-length relationship.

- Modular governance emerges when suppliers make products to a customer's specifications that are complex but relatively easy to codify. By exchanging information in the form of standards, buyers and suppliers reduce coordination costs.

- Relational governance exists when buyers and suppliers rely on complex information that is not easily transmitted. Frequent interactions and knowledge sharing based on mutual trust and social ties between parties are critical in coordinating relational chains.

- Captive governance is characterized by a group of small suppliers that are dependent on one or a few buyers in their resources and market access. Captive suppliers tend to operate under conditions set by, and often specific to, particular buyers.

- Hierarchical governance describes chains characterized by vertical integration and managerial control within lead firms that develop and manufacture products in-house. 
Figure A1 - Electric motor value chain. The figure reports the main production stages, products and lead companies' names - Adapted from Lowe et al. (2010)

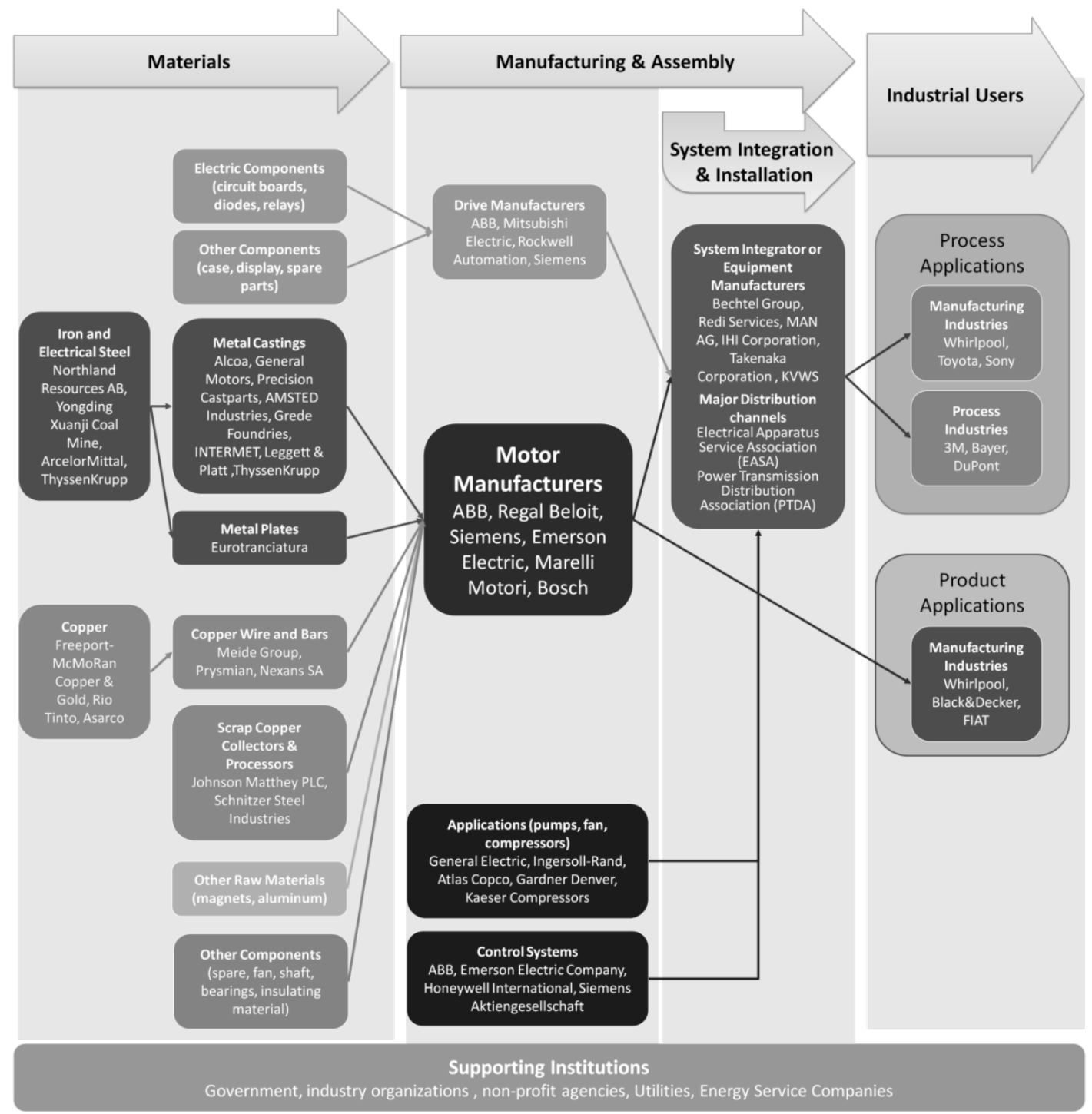


Table A1 - Suppliers and their location: domestic (white cells), European or mixed global/domestic (light grey cells) or global (dark grey cells). In brackets parts and components that are internally made.

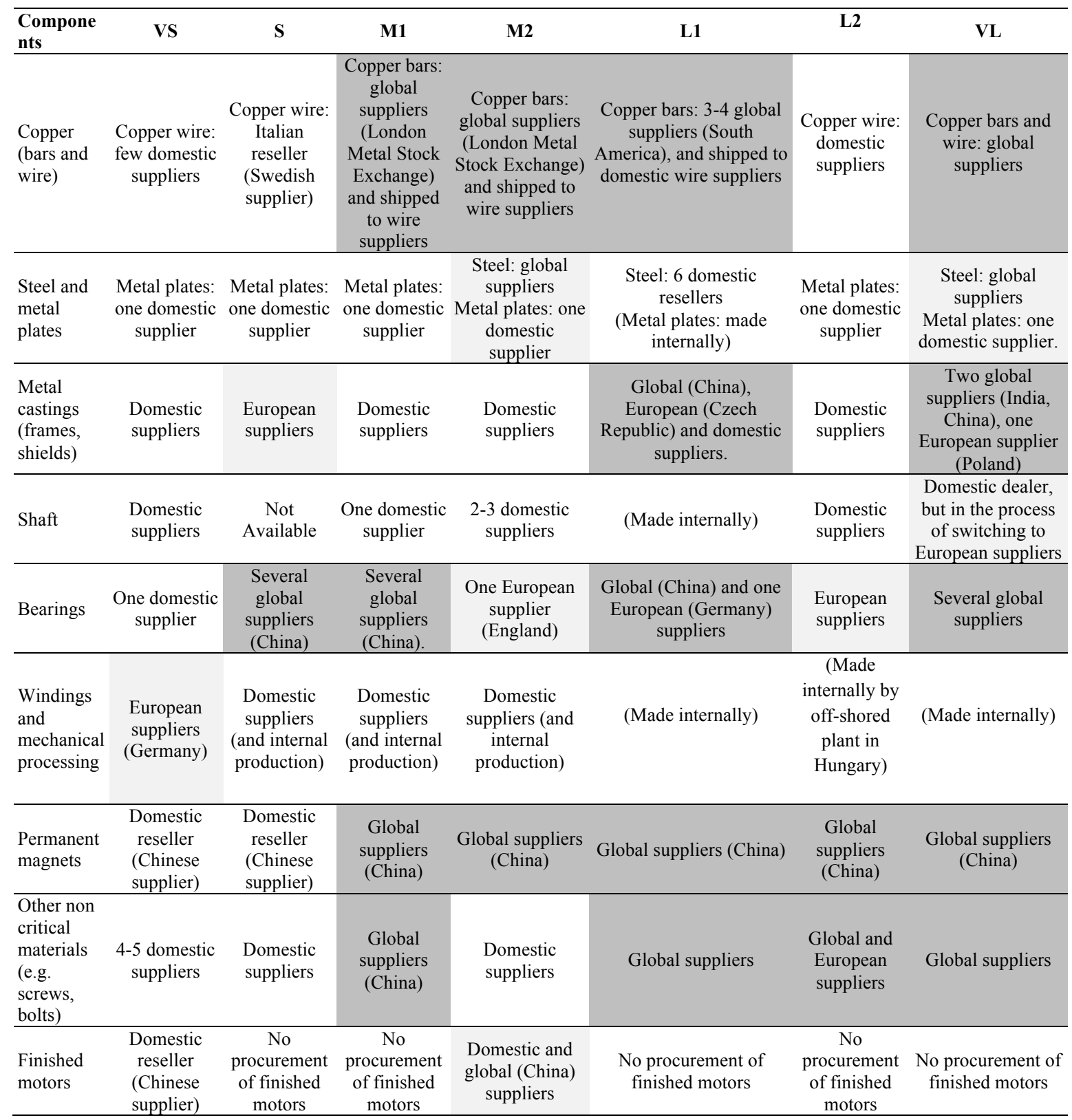


Table A2 - Technological and operational integration with suppliers

\begin{tabular}{|c|c|c|c|c|c|}
\hline \multicolumn{3}{|c|}{ Technological Collaboration } & \multicolumn{3}{|c|}{ Operational Collaboration } \\
\hline & Co-design & Joint teams & Long term relationships & $\begin{array}{l}\text { Information } \\
\text { sharing }\end{array}$ & $\begin{array}{c}\text { Physical } \\
\text { integratio } \\
n \\
\end{array}$ \\
\hline VS & $\begin{array}{l}\text { Yes (shaft and metal } \\
\text { castings) }\end{array}$ & & Yes, but informal & & \\
\hline $\mathbf{S}$ & & & Yes, but informal & & \\
\hline M1 & $\begin{array}{l}\text { Yes (shaft and metal } \\
\text { castings) }\end{array}$ & & $\begin{array}{l}\text { Frame agreements of } 3,6 \text { or } 12 \\
\text { months (fixed or indexed prices) }\end{array}$ & $\begin{array}{l}\text { Shared production } \\
\text { plans }\end{array}$ & \\
\hline M2 & $\begin{array}{l}\text { Yes (shaft and metal } \\
\text { castings) }\end{array}$ & $\begin{array}{l}\text { Yes (design of the } \\
\text { finished motors) }\end{array}$ & $\begin{array}{l}\text { Frame agreements of } 3,6 \text { or } 12 \\
\text { months (fixed or indexed prices) }\end{array}$ & $\begin{array}{l}\text { Shared production } \\
\text { plans }\end{array}$ & \\
\hline L1 & & $\begin{array}{l}\text { Yes (design of the } \\
\text { metal castings) }\end{array}$ & $\begin{array}{l}\text { Frame agreements of } 3,6 \text { or } 12 \\
\text { months (fixed or indexed prices) }\end{array}$ & $\begin{array}{l}\text { Rolling forecast and } \\
\text { shared weekly } \\
\text { production plans }\end{array}$ & $\begin{array}{c}\text { Electronic } \\
\text { kanban } \\
\text { system }\end{array}$ \\
\hline $\mathbf{L 2}$ & & $\begin{array}{l}\text { Yes (design of the } \\
\text { metal castings) }\end{array}$ & $\begin{array}{l}\text { Frame agreements of } 3,6 \text { or } 12 \\
\text { months (fixed or indexed prices) }\end{array}$ & $\begin{array}{l}\text { Shared production } \\
\text { plans }\end{array}$ & \\
\hline VL & & $\begin{array}{l}\text { Yes (design of the } \\
\text { metal castings) }\end{array}$ & $\begin{array}{l}\text { Frame agreements of } 3,6 \text { or } 12 \\
\text { months (fixed or indexed prices) }\end{array}$ & $\begin{array}{l}\text { Exchange of } 3,6 \text { and } \\
12 \text { months forecasts. } \\
\text { Order tracking and } \\
\text { tracing }\end{array}$ & \\
\hline
\end{tabular}

Table A3-Technological and operational integration with customers

\begin{tabular}{|c|c|c|c|}
\hline \multicolumn{2}{|r|}{ Technological Collaboration } & \multicolumn{2}{|c|}{ Operational Collaboration } \\
\hline & Co-design & $\begin{array}{l}\text { Long term } \\
\text { relationships }\end{array}$ & Information sharing \\
\hline VS & (Very rare) & - & \\
\hline $\mathbf{S}$ & Yes, for fully customized motors & - & $\begin{array}{l}\text { Informal information } \\
\text { exchange. } \\
\text { Order tracking for } \\
\text { main customers }\end{array}$ \\
\hline M1 & Yes & - & \\
\hline M2 & $\begin{array}{c}\text { Yes } \\
\text { (motor and fan system) }\end{array}$ & - & \\
\hline L1 & Yes, in collaboration with the sales units & Frame agreements & $\begin{array}{c}\text { Use of an eCommerce } \\
\text { portal for exchanging } \\
\text { information }\end{array}$ \\
\hline $\mathbf{L 2}$ & $\begin{array}{c}\text { Limited } \\
\text { (company produces on customers' specs) }\end{array}$ & Frame agreements & Production plans \\
\hline VL & Yes, for with new customers and in collaboration with the sales units & Frame agreements & $\begin{array}{l}\text { Order tracking and } \\
\text { tracing }\end{array}$ \\
\hline
\end{tabular}




\section{Tables}

Table 1 - Case studies set

\begin{tabular}{|c|c|c|c|c|}
\hline \multirow[b]{2}{*}{ Case Size } & \multirow{3}{*}{$\begin{array}{l}\text { Employees } \\
<10\end{array}$} & \multicolumn{2}{|l|}{ Interviewed } & \multirow[b]{2}{*}{ Production facilities } \\
\hline & & person(s) & Type of company & \\
\hline $\begin{array}{ll}\text { VS } & \text { Very Small }\end{array}$ & & Owner & Motor manufacturer & 1 in Italy \\
\hline Small & $<20$ & Owner & Motor manufacturer & 1 in Italy \\
\hline M1 Medium & 85 & $\begin{array}{l}\text { Managing Director, } \\
\text { Controller }\end{array}$ & Motor manufacturer & 3 in Italy \\
\hline M2 Medium & 100 & $\begin{array}{l}\text { President and } \\
\text { Director } \\
\text { Operations }\end{array}$ & Motor manufacturer & 1 in Italy \\
\hline Large & 550 & Operations Director & Motor manufacturer & 1 in Italy and 1 Malaysia \\
\hline Large & 360 & Managing director & Motor manufacturer & 1 in Italy, 1 in Hungary \\
\hline VL Very Large & 700 & $\begin{array}{l}\text { Plant purchasing } \\
\text { manager, buyer }\end{array}$ & Motor manufacturer & $\begin{array}{l}\text { China, } 1 \text { in South Africa and } 1 \\
\text { in Brazil. }\end{array}$ \\
\hline Su1 Large & 511 & Logistic director & Supplier & 1 in Italy \\
\hline Su2 Small & 25 & Owner & Supplier & 1 in China \\
\hline
\end{tabular}


Table 2 - Level of global sourcing and distribution of the cases (percentage of spending and turnover). Global stands for outside Europe.

\begin{tabular}{lll}
\hline & Global Sourcing & Global Distribution \\
\hline VS & $0 \%$ global & Almost $0 \%$ global \\
& $(100 \%$ domestic $)$ & $(100 \%$ domestic $)$ \\
\hline S & $5 \%$ global & Almost $0 \%$ global \\
& $(80 \%$ domestic; $15 \%$ Europe $)$ & $(86 \%$ domestic; $14 \%$ Europe $)$ \\
\hline M1 & $20 \%$ global & Almost $0 \%$ global \\
& $(80 \%$ domestic $)$ & $(50 \%$ domestic; $50 \%$ Europe $)$ \\
M2 & $50 \%$ global & Almost $0 \%$ global \\
& $(50 \%$ domestic and Europe $)$ & $(70 \%$ domestic; $30 \%$ Europe $)$ \\
\hline L1 & $60 \%$ global & $70 \%$ global \\
& $(40 \%$ domestic and Europe $)$ & $(30 \%$ domestic and Europe $)$ \\
\hline L2 & $10 \%$ global & $3 \%$ global \\
& $(85 \%$ domestic; $5 \%$ Europe $)$ & $(54 \%$ domestic; $43 \%$ Europe $)$ \\
\hline & $50 \%$ global & $60 \%$ global \\
& $(10 \%$ domestic; $40 \%$ Europe $)$ & $(10 \%$ domestic; $30 \%$ Europe $)$ \\
\hline & & \\
\hline
\end{tabular}


Table 3 - Identification of governance structures for the different purchasing categories

\begin{tabular}{|c|c|c|c|c|c|}
\hline \multirow[b]{2}{*}{ Component } & \multicolumn{3}{|c|}{ Key determinants of GVC Governance } & \multirow{2}{*}{$\begin{array}{l}\text { Category (used } \\
\text { in Figure 4) }\end{array}$} & \multirow[b]{2}{*}{$\begin{array}{l}\text { Outcome: } \\
\text { Type of } \\
\text { governance }\end{array}$} \\
\hline & $\begin{array}{c}\text { Complexity } \\
\text { of } \\
\text { transaction } \\
\end{array}$ & $\begin{array}{c}\text { Ability to } \\
\text { codify } \\
\text { transactions } \\
\end{array}$ & $\begin{array}{c}\text { Capabilities in } \\
\text { the supply- } \\
\text { base }\end{array}$ & & \\
\hline Copper & Low & High & High & \multirow{2}{*}{ Raw materials } & \multirow[t]{2}{*}{ Market } \\
\hline Steel and metal plates & Low & High & High & & \\
\hline $\begin{array}{c}\text { Metal castings } \\
\text { (frames, shields) } \\
\end{array}$ & Medium & Medium & High & \multirow{3}{*}{$\begin{array}{l}\text { Customized } \\
\text { components }\end{array}$} & \multirow{3}{*}{$\begin{array}{l}\text { Modular- } \\
\text { Relational }\end{array}$} \\
\hline Shaft & Medium & High & Medium & & \\
\hline Finished motors & Medium & Medium & Medium & & \\
\hline Bearings & Low & High & High & \multirow{3}{*}{$\begin{array}{c}\text { Standard } \\
\text { components }\end{array}$} & \multirow{3}{*}{ Market } \\
\hline Permanent magnets & Low & High & High & & \\
\hline $\begin{array}{l}\text { Other non critical } \\
\text { materials (e.g. } \\
\text { screws, bolts) }\end{array}$ & Low & High & High & & \\
\hline $\begin{array}{c}\text { Windings and other } \\
\text { mechanical } \\
\text { processing }\end{array}$ & High & High & Medium & $\begin{array}{l}\text { Outsourced } \\
\text { activities }\end{array}$ & $\begin{array}{l}\text { Relational- } \\
\text { Captive }\end{array}$ \\
\hline
\end{tabular}


Table 4 - Competitive priorities pursued by cases belonging to different configurations. (OW: order winner; $M Q$ : market qualifier)

\begin{tabular}{lcc}
\hline & VS, S, M1 & M2, L1, L2, VL \\
\hline Flexibility & OW & \\
Delivery speed & OW & \\
Customization & OW & OW \\
Quality & MQ & MQ \\
After sales service & & OW \\
Price & & MQ \\
\hline
\end{tabular}




\section{Figures}

Figure 1 - Positioning of the cases over the GVC (white boxes represent the production stages performed by at least one case)

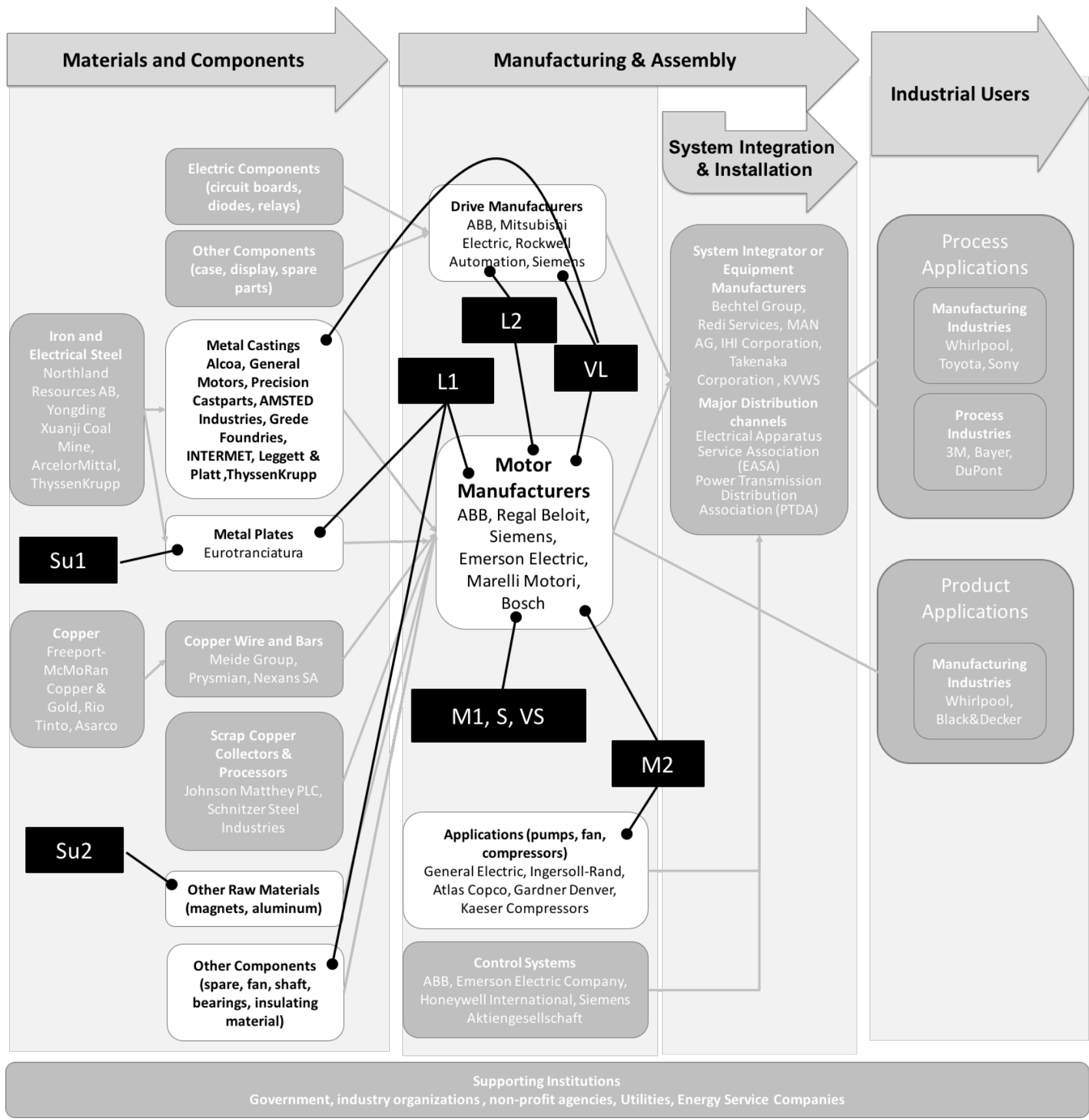


Figure 2-Common features of the cases in the governance typologies and SC management (G: level of gobalization, TC: technological collaboration; OC: operational collaboration. The intensity can range among low-mid-high).

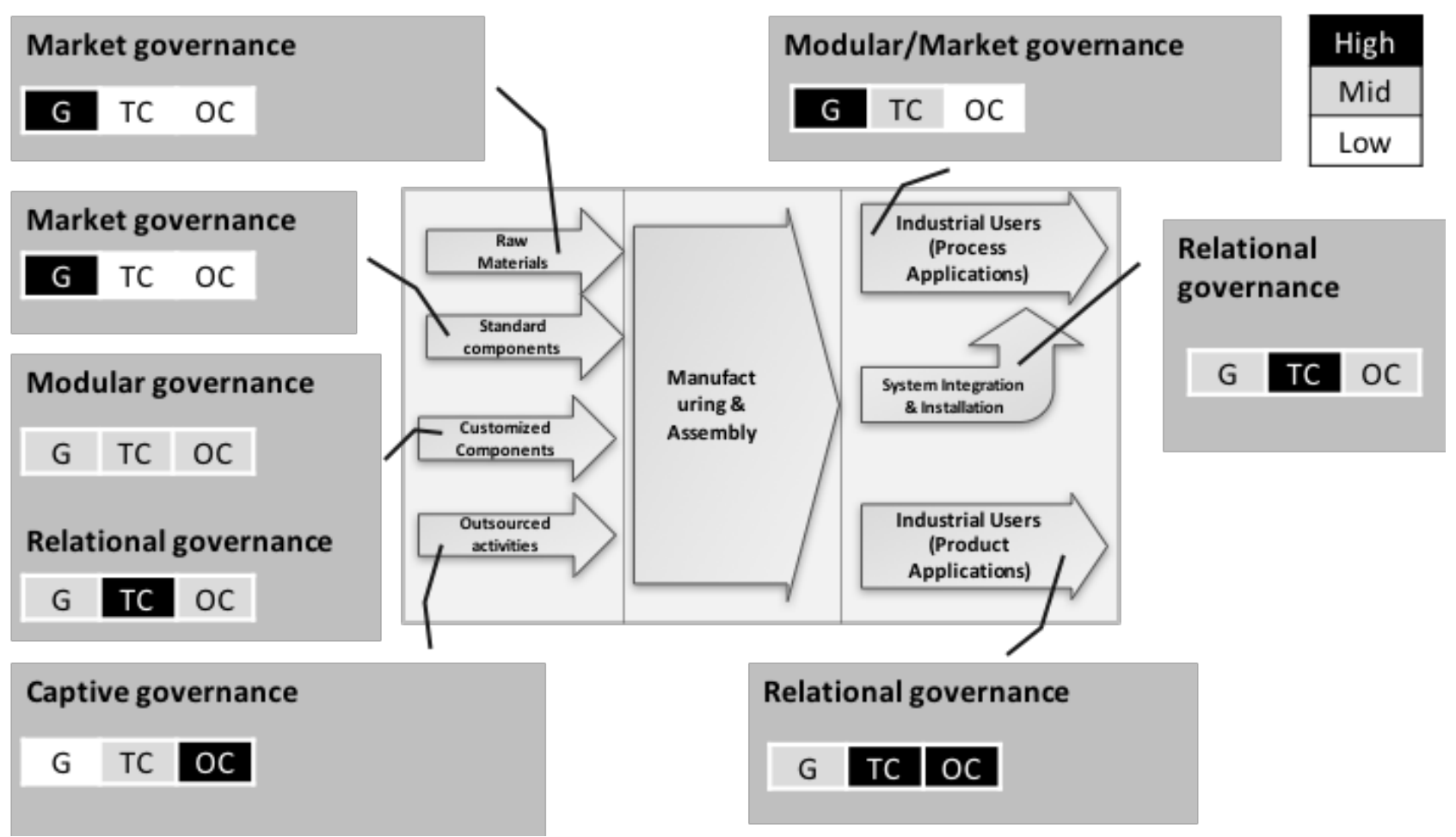


Figure 3 -Distinctive behaviours displayed by the cases

- S and VS buy from intermediaries

- VL and L1 directly negotiate with global suppliers and they set frame agreements with them

- VL and $\mathrm{L} 1$ have risk management programs in place

- M2, L1 and VL tend to rely on global suppliers with more intense use of frame agreement and operational collaboration

- VS, S, M1 and L2 use local suppliers with more informal exchange of information

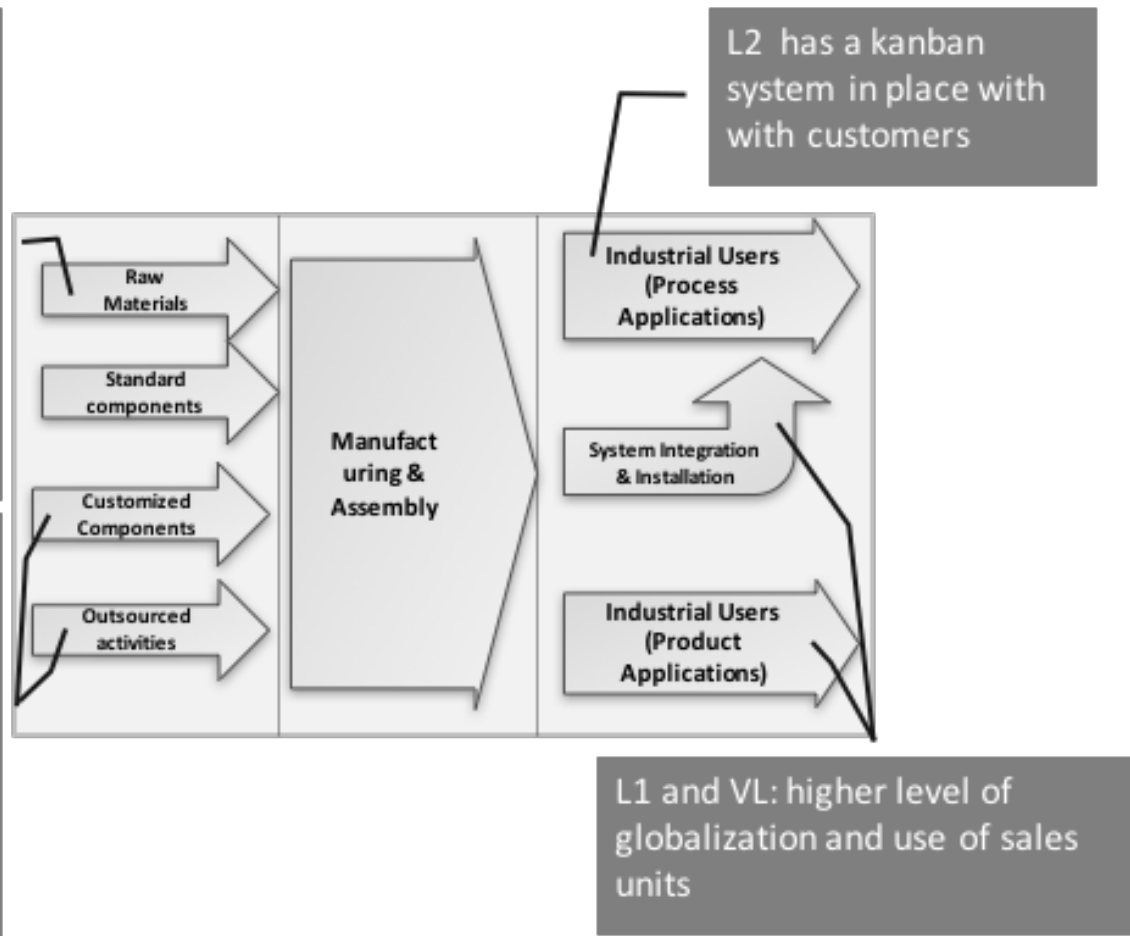


Figure 4 - The research framework and findings

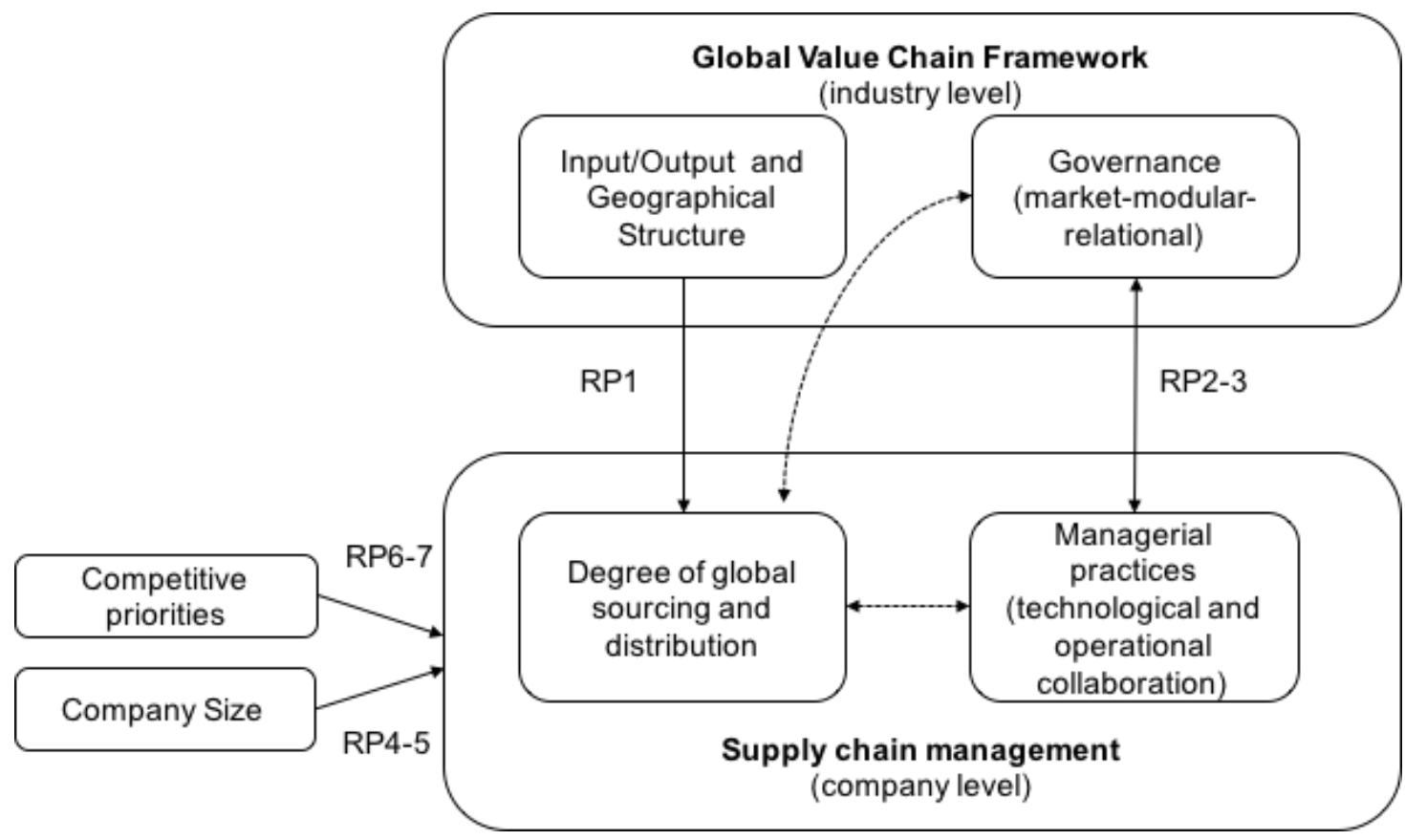

